\title{
Does IFRS Mandatory Adoption Affect Information Asymmetry in the Stock Market?
}

\author{
David Abad, University of Alicante \\ M. Fuensanta Cutillas-Gomariz, University of Murcia \\ Juan Pedro Sánchez-Ballesta, University of Murcia \\ José Yagüe, University of Murcia
}

\begin{abstract}
The purpose of International Financial Reporting Standards (IFRS), adopted mandatorily by European listed firms in 2005, is to increase the transparency and the comparability of accounting information, which should have led to improvements in these firms' information environment. This study uses market microstructure proxies for information asymmetry to examine the effects of IFRS adoption on the level of information asymmetry in the Spanish stock market. Therefore, we consider a setting with substantial differences between local standards - Spanish Accounting Standards (SAS) - and IFRS and where the level of enforcement is low. By controlling for conventional determinants of information asymmetry and firms' characteristics that influence their information environment, we find a reduction of information asymmetry after IFRS adoption. Our findings suggest that the mandatory switch from local accounting standards to IFRS conveys benefits to the market, even when the enforcement level is not strong.
\end{abstract}

I $\mathrm{n}$ this paper we investigate the relation between the mandatory adoption of International Financial Reporting Standards (IFRS) and information asymmetry in the equity market, using direct measures of information asymmetry derived from the microstructure literature. The adoption of IFRS around the world has been one of the most important regulatory changes in financial reporting in many years. In particular, European Union (EU) Regulation No. 1606/2002 requires listed companies to prepare their consolidated financial statements according to IFRS as of 1 January 2005. The purpose of this regulatory change is to improve the comparability and transparency of accounting information (European Communities 2002). This should have led to financial statements of higher informational quality for market participants and potential beneficial economic consequences on the market. As a result, the switch to IFRS has generated extensive empirical literature about its economic consequences on financial reporting quality and capital markets in general. ${ }^{1}$ Most of the previous empirical literature examining the market consequences of IFRS adoption has found positive market effects in terms of liquidity and the cost of capital (Daske et al. 2008, 2013; Li 2010; Christensen et al. 2013), and also, by examining its effects on analyst forecast accuracy and consensus on the information environment (Tan et al. 2011; Byard et al. 2011; Horton et al. 2013). This empirical evidence is consistent with the idea that higher accounting information quality and increased disclosure derived from IFRS adoption (Barth et al. 2008) should achieve one of the main objectives of standard setters, which is to increase investor confidence through the reduction of information asymmetry.

Theoretical and empirical research shows that increased financial reporting transparency and disclosure reduce information asymmetry between investors by decreasing private information search incentives and by lowering the amount of private information compared to publicly available information (Diamond 1985; Diamond and Verrechia 1991; Easley and O'Hara 2004). Lower levels of information asymmetry benefit investors because they lead to more-informed valuation, so reducing adverse selection risk and, hence, increasing market liquidity (e.g. Glosten and Milgron 1985). Consequently, information asymmetry proxies should reflect, among other things, firms' accounting quality (Leuz 2003). Therefore, if IFRS adoption really implies an increase in financial reporting quality or disclosure, and/or

Correspondence: Juan Pedro Sánchez Ballesta, University of Murcia, Faculty of Economics and Business, Department of Financial Economics and Accounting, Campus de Espinardo, s/n, 30100 Murcia, Spain. Tel: +34 868883807; fax: +34 868887794; email: juanpsb@um.es 
enhances financial information comparability, so, according to economic theory, the market benefits after IFRS adoption can be attributed to the change in accounting standards. However, in the recent accounting literature there is an ongoing debate about whether the post-IFRS market benefits have been driven by the change in the accounting standards per se or by other related factors that include: a) institutional factors such as the level of the enforcement of the country and the extent of enforcement changes made to support the implementation of IFRS; b) firms' reporting incentives; and c) the degree of similarity between IFRS and preceding local Generally Accepted Accounting Principles (GAAP).

Most previous studies argue that, at the national level, post-IFRS liquidity benefits appear in countries with high enforcement or with concurrent changes in reporting enforcement, or, at the firm level, they depend on firm's reporting incentives. In particular, Daske et al. (2008) and Li (2010) find that capital market benefits occur in countries with strong legal enforcement mechanisms and where firms have more incentives to be transparent. Considering firm level heterogeneity in examining the economic consequences around International Accounting Standards (IAS) and IFRS adoptions, Daske et al. (2013) conclude that reductions in the cost of capital and increases in liquidity are found in those firms with higher changes in their reporting incentives, that is, in those that increase their commitment to transparency after IAS/IFRS adoptions. Christensen et al. (2013) try to disentangle the effects of switching to IFRS from those motivated by concurrent changes in enforcement, and find that the liquidity increase is concentrated in those EU countries that improved their reporting enforcement. Thus, they conclude that the liquidity benefits observed around IFRS adoption are driven basically by the changes in enforcement more than by the accounting standards changes themselves. Barth and Israeli (2013), in contrast, believe that the Christensen et al. (2013) findings suggest that it is the combination of changes in accounting standards to IFRS and advances in enforcement that convey liquidity benefits.

Regarding the influence of the degree of similarity between IFRS and preceding local GAAP, the evidence is not conclusive. Several studies have found that the extent of the differences between prior domestic standards and IFRS is positively associated with the increase in analyst following (Tan et al. 2011) and analyst forecast accuracy (Byard et al. 2011). In contrast, Brochet et al. (2013) report that the adoption of IFRS leads to informational benefits, even in a country whose domestic standards present few differences with IFRS, as is the United Kingdom (UK).

To shed further light on the debate surrounding the main determinants of the market benefits following IFRS adoption, we examine the IFRS effects on the level of information asymmetry in the Spanish Stock Exchange. ${ }^{2}$
Our study provides new evidence, that could be valuable for at least two reasons. First, we analyse IFRS adoption using market microstructure measures estimated from high frequency data, that is, the bid-ask spread, the illiquidity measure developed in Amihud (2002), the price impact introduced by Huang and Stoll (1996), the Probability of Informed Trading (PIN) of Easley et al. (1996), the Volume-synchronised Probability of Informed Trading (VPIN) of Easley et al. (2012), and an index of information asymmetry as the first principal component of the five former measures. Bid-ask spread is a commonly used proxy for information asymmetry because it compensates liquidity providers for transacting with better-informed traders and it increases with the degree of information asymmetry. The measures that capture price impact of transactions - the illiquidity measure of Amihud (2002) and the price impact of Huang and Stoll (1996) - appear to be important in describing the arrival of new information to market participants. The well-known measures of PIN and the novel VPIN directly infer the presence of privately informed traders in the market from the computation of order imbalances between buys and sells. As well as testing these measures individually, we construct an index of adverse selection from this set of market microstructure measures, which allows us to extract the common variation in all these information asymmetry measures and, in this way, we minimise the possibility that these proxies are driven by other factors different from adverse selection, that is, inventory costs, transactions costs, and so on. Second, we focus on the Spanish market, which can be considered a suitable setting for understanding the capital market effects of IFRS adoption. As in all the other EU countries, the Spanish firms listed on secondary stock markets have been mandatorily required to prepare their consolidated financial statements in accordance with IFRS since 2005. Spain is a country characterised by low enforcement (La Porta et al. 1998; Kaufmann et al. 2009) and high disparity between Spanish Accounting Standards (SAS) and IFRS in terms of standards and disclosure requirements (Bae et al. 2008; Nobes 2011). Therefore, the chosen setting is appropriate for the analysis of the consequences of the accounting change, since we avoid selection bias of voluntary adopters (Ashbaugh 2001) and we deal with a context without concurrent changes in the legal environment and enforcement (Choi et al. 2013). Effectively, in Spain, the accounting changes and, in particular, the increases in disclosure requirements implied by IFRS are implemented without relevant concurrent enforcement changes. Hence, if we find a reduction in the level of information asymmetry after IFRS adoption, this result supports the arguments that IFRS confer information asymmetry benefits when the distance between local GAAP and IFRS is high, even though the enforcement level is low and the reporting enforcement changes around the adoption of IFRS are not 
important. This reduction of information asymmetry could be driven by the relevant accounting change per $s e$, which enhances financial reporting transparency and disclosure. On the contrary, a non-significant result would be consistent with the view that IFRS adoption by itself does not provide capital market benefits, at least with regards to information asymmetry.

To conduct our analyses, we constructed a balanced panel of Spanish non-financial firms for the period 20012008. By controlling for market determinants of information asymmetry and firms' characteristics, we find a significant reduction in the level of information asymmetry among investors in the Spanish Stock Exchange after IFRS adoption. Overall, we find significant and consistent decreases in five out of our six proxies for information asymmetry, which means that IFRS had an effect not only on liquidity, but also on the level of information asymmetry among market participants. After implementing several sensitivity analyses we confirm that this post-IFRS improvement in information asymmetry is not simply due to time effects, and we also find that the reduction in information asymmetry is stronger in those firms with higher concentrated ownership, which are usually characterised as less proactive to disclose information. Overall, these findings suggest that the higher disclosure and transparency requirements implied by IFRS adoption have benefited the information environment of Spanish firms.

Our study contributes to the literature by providing new empirical evidence to the debate on the market effects of IFRS by using measures of adverse selection developed by market microstructure literature. To the best of our knowledge, this is the first study that uses measures such as PIN, VPIN, and a composite index of adverse selection to examine the effects of IFRS adoption on the levels of information asymmetry in the market. Prior studies researching into the effects of IFRS on the information environment have mainly focused on proxies that can be considered as indirect measures of information asymmetry, such as the accuracy of financial analysts' forecasts (e.g. Byard et al. 2011, Tan et al. 2011), liquidity measures and the cost of capital (e.g. Daske et al. 2008, 2013; Li 2010; Christensen et al. 2013). As Bharath et al. (2009) argue, the use of an index of information asymmetry based on market microstructure measures has more desirable properties than using individual proxies proposed by the corporate finance literature (e.g. analyst coverage, dispersion of analysts' forecasts, tangibility of assets), because these measures are often inconsistent, static, persistent, and have multiple and ad hoc interpretations. In addition, using the proxies individually allows us to examine the channel through which IFRS affects information asymmetry. Moreover, since IFRS adoption may be associated with higher disclosure and financial reporting quality, our results also extend previous literature on the market effects of disclosure and accounting quality (Diamond and Verrechia 1991; Easley and O'Hara 2004; Lambert et al. 2007, 2012).

The rest of the paper proceeds as follows. Section 2 describes the measures of information asymmetry used. Section 3 describes the research design, sample selection, and data. Section 4 presents the descriptive statistics and empirical results. Section 5 concludes.

\section{Measures of Information Asymmetry}

Information asymmetry is a key concept in capital markets because it affects stock liquidity (Kyle 1985), which in turn has an effect on asset pricing and on the cost of capital (e.g. Amihud and Mendelson 1986; Easley and O'Hara 2004). Empirically capturing the level of information asymmetry in a firm's market valuation is a difficult task since information asymmetry is not directly observable. The market microstructure literature has proposed different measures and procedures to capture financial market perceptions of adverse selection risk, which arises when some traders possess private information not currently reflected in stock prices. In contrast to the measures introduced by corporate finance, market microstructure exploits several sources of information contained in intraday data to capture the presence of traders with better information (informed traders). Nevertheless, in the literature there has always been a debate about the appropriateness of each proxy in measuring information-based trading. All measures of information asymmetry are imperfect proxies for the financial market's perception of the adverse selection between informed and uninformed traders. For this reason, to obtain a more accurate information asymmetry measure, prior studies (e.g. Bharath et al. 2009) use principal component analysis to extract the first principal component from individual proxies for information asymmetry. In this paper, as well as testing the IFRS effect on five individual proxies of information asymmetry developed by market microstructure literature - bid-ask spread, illiquidity measure, price impact, PIN, and VPIN - we create an adverse selection index (denoted as ASY hereafter) applying principal component analysis to these measures.

\section{Bid-ask spread}

The first and effortless proxy for asymmetric information is the bid-ask spread, a widely used measure of trading costs (liquidity). Bid-ask spread incorporates a component related to the liquidity providers' protection from being adversely selected. Glosten and Milgrom (1985) and Easley and O'Hara (1992) theoretically show that the sole presence of traders with different levels of information is reason enough for the existence of the 
bid-ask spread. We estimate the relative quoted spread, $Q S P D$, which is defined as

$$
\mathrm{QSPD}_{t}=\frac{a_{t}-b_{t}}{\mathrm{Q}_{t}}
$$

where $a_{t}$ and $b_{t}$ correspond to the ask and the bid quotes in $t$. $Q_{t}=\left(a_{t}+b_{t}\right) / 2$ is the quoted midpoint in $t$, commonly used as a proxy for the efficient price. For each asset, we calculate a yearly equally-weighted mean from daily relative quoted spreads, which we compute as the time-weighted average of relative quote spreads registered over a day.

\section{Illiquidity measure}

Since adverse selection is an important determinant of stock liquidity, we estimate the index of illiquidity introduced by Amihud (2002), which is a volume-based liquidity indicator defined as

$$
A M H_{t}=\frac{1}{D_{t}} \sum_{d=1}^{D_{t}} \frac{\left|R_{d t}\right|}{V_{d t}}
$$

where $R_{d, t}$ is the return on day $d$ on year $t, V_{d t}$ is the volume in euros on day $d$ on year $t$, and $D_{t}$ is the number of days for which data are available in year $t$. This illiquidity measure gives the average of the daily price impact of the order flow or the absolute percentage price change associated with a unit of trading volume. When a stock is liquid, large trading volumes provoke small price changes. Therefore, higher values of $\mathrm{AMH}$ indicate higher price moves in response to trading volume, and thus higher stock illiquidity. It is expected that the greater the extent of information asymmetry, the worse stock liquidity will be, and the greater AMH will be. ${ }^{3}$ We use the yearly mean of the daily AMH values, and following Amihud (2002), we multiply AMH by $10 .^{6}$

\section{Price impact}

The illiquidity index of Amihud (2002) provides a rough measure of price impact. Trades initiated by noise traders lead to transitory changes in transaction prices, while information-based trades provoke permanent price changes. Huang and Stoll (1996) introduce the realised spread (or price reversal) and the price impact by considering the quote adjustment that takes place a period of time after a trade to extract the presence of new information. Price impact $(P I)$ is the permanent price change (or information content) of a trade and is defined as

$$
P I_{t+\tau}=\left(Q_{t+\tau}-Q_{t}\right) X_{t}
$$

where $Q_{t}$ is the quote midpoint defined previously, $X_{t}$ is a trade indicator variable taking the value -1 if the trade in $t$ is initiated in the sell side and 1 if it is initiated in the buy side. Finally, $\tau$ is the period of time for prices to fully reflect the information content in trade $t$. We use 1-, 5- and 30-minute periods to estimate $P I{ }^{4} P I$ is also computed in trade-time by averaging (volumeweighted) all the trades within the day and, after that, by averaging (equally-weighted) all the trading days within the year. A large and positive PI indicates a high frequency of information-based trades.

\section{Probability of informed trading (PIN)}

The PIN is the unconditional probability that a randomly selected trade originates from an informed trader. The PIN is a measure based on the theoretical work of Easley and O'Hara (1987, 1992), although the original PIN model was introduced by Easley et al. (1996). The $P I N$ is not directly observable but is a function of the theoretical parameters of a microstructure model that have to be estimated by numerical maximisation of a likelihood function. The PIN model considers trading as a game between liquidity providers and traders (position takers) that is repeated over trading days. Trades can come from informed or uninformed traders. For any given trading day the arrival of buy and sell orders from uninformed traders, who are not aware of the new information, is modeled as two independent Poisson processes with daily arrival rates $\varepsilon_{b}$ and $\varepsilon_{S}$, respectively. The model assumes that information events occur between trading days with probability $\alpha$. Informed traders only trade on days with information events, buying if they have seen good news (with probability $1-\delta$ ) and selling if they have seen bad news (with probability $\delta$ ). The orders from the informed traders follow a Poisson process with a daily arrival rate $\mu$.

Under this model, the likelihood of observing $B$ buys and $S$ sells on a single trading day is

$$
\begin{aligned}
& L((B, S) \mid \theta)=(1-\alpha) e^{-\varepsilon_{b}} \frac{\left(\varepsilon_{b}\right)^{B}}{B !} e^{-\varepsilon_{s}} \frac{\left(\varepsilon_{s}\right)^{S}}{S !} \\
& +\alpha \delta e^{-\varepsilon_{b}} \frac{\left(\varepsilon_{b}\right)^{B}}{B !} e^{-\left(\varepsilon_{s}+\mu\right)} \frac{\left(\varepsilon_{s}+\mu\right)^{S}}{S} \\
& +\alpha(1-\delta) e^{-\left(\varepsilon_{b}+\mu\right)} \frac{\left(\varepsilon_{b}+\mu\right)^{B}}{B !} e^{-\varepsilon_{s}} \frac{\left(\varepsilon_{s}\right)^{S}}{S !}
\end{aligned}
$$

where $B$ and $S$ represent total buy trades and sell trades for the day respectively, and $\theta=\left(\alpha, \delta, \mu, \varepsilon_{b}, \varepsilon_{s}\right)$ is the parameter vector. This likelihood function is a mixture of three Poisson probabilities, weighted by the probability of having a 'good news day' $\alpha(1-\delta)$, a 'bad news day' $\alpha \delta$, and 'no-news day' $(1-\alpha)$. Assuming cross-trading 
day independence, the likelihood function across $J$ days is simply the product of the daily likelihood functions:

$$
L(M \mid \theta)=\prod_{j=1}^{J} L\left(\theta \mid B_{j}, S_{j}\right)
$$

where $B_{j}$, and $S_{j}$ are the numbers of buy and sell trades for day $j=1, \ldots, J$, and $M=\left[\left(B_{1}, S_{1}\right), \ldots,\left(B_{J}, S_{J}\right)\right]$ is the data set. Maximisation of (5) over $\theta$ given the data $M$ yields maximum likelihood estimates for the underlying structural parameters of the model $(\alpha, \delta, \mu$, $\left.\varepsilon_{b}, \varepsilon_{s}\right)$. Once the parameters of interest are estimated, the $\mathrm{PIN}$ is calculated as

$$
P I N=\frac{\alpha \mu}{\alpha \mu+\varepsilon_{b}+\varepsilon_{s}}
$$

where $\alpha \mu+\varepsilon_{b}+\varepsilon_{s}$ is the arrival rate of all orders and $\alpha \mu$ is the arrival rate of informed orders. The PIN is therefore the ratio of orders from informed traders to the total number of orders.

An attractive feature of the PIN methodology is its apparently modest data requirement. All that is necessary to estimate the model is the number of buy- and sell-initiated trades for each stock and each trading day. However, one shortcoming of the methodology is that, although the estimation procedure is straightforward, it often encounters numerical problems when performing the estimation in practice. Especially in stocks with a huge number of trades, the optimisation program may clash with computational overflow or underflow (floating-point exception) and, as a consequence, it may not be able to obtain an optimal solution. These difficulties in estimating PIN have been exacerbated in recent years due to the steady increase in the number of trades whichthat are a consequence, among other reasons, of the growth in automated trading and structural changes in the market, which have greatly reduced market depth (Aslan et al. 2011). To estimate PIN we use the computational-friendly likelihood function proposed by Lin and Ke (2011) using Matlab software. To set initial values we follow the process described in Gan et al. (2015) that assists the maximum likelihood estimation process both in terms of speed and accuracy. ${ }^{5}$. We finally use the yearly mean of the monthly PIN estimates. ${ }^{6}$

\section{Volume-synchronised probability of informed trading (VPIN)}

As an update of the PIN model, Easley et al. (2012) have developed a new measure for adverse selection risk called Volume-synchronised Probability of Informed Trading or VPIN. The VPIN approach has some practical advantages over the PIN methodology that make it particularly attractive for both practitioners and researchers. The main advantage is that VPIN does not require the estimation of non-observable parameters using optimisation or numerical methods, thereby avoiding all the associated computational problems and biases. In particular, VPIN measures order flow toxicity, which can be considered as a broader concept for adverse selection applied to the particular world of liquidity providers in a high frequency trading (HFT) environment. Abad and Yagüe (2012) show that VPIN can be considered as a more flexible measure of asymmetric information that can be applied in a wide range of frameworks by choosing the appropriate values of the variables involved in the estimation process. There are three relevant variables in the VPIN approach: time bar, volume bucket and sample length. Below, we briefly review the three levels in which the VPIN calculation takes place (for a more accurate description of the procedure, see the original paper of Easley et al. 2012; for a numeric example of this procedure, see Abad and Yagüe 2012).

1. Time bars The original procedure begins with trade aggregation in time bars. Bar size is the first key variable of the VPIN computation process. Easley et al. (2012) initially use 1-minute time bars. In each time bar, trades are aggregated by adding the volume of all the trades in the bar (if any) and by computing the price change for this period of time. Afterwards, and in order to take into account trade size, the sample is 'expanded' by repeating each bar price change a number of times equal to the number of shares traded in the bar. Thus, the original raw sample becomes a sample of one-unit trades, each associated with the price change of the corresponding bar.

2. Volume buckets, bulk classification and order imbalance Volume bucket is the second essential variable in VPIN metrics. Volume buckets represent pieces of homogeneous information content that are used to compute order imbalances. In Easley et al. (2012) volume bucket size (VBS) is calculated by dividing the average daily volume (in shares) by 50 , which is the number of buckets they initially consider. Therefore, if we depart from the average daily volume, it is the number of buckets which fully determines VBS. Consequently, we consider the number of buckets as our second key variable. Buckets are filled by adding the volume in consecutive time bars until completing the VBS. If the volume of the last time bar needed to complete a bucket is for a size greater than that required, the excess size is given to the next bucket. In general, a volume bucket needs a certain number of time bars to be completed although it is also possible that the volume in a time bar could be enough to fill one (or more) volume buckets. At the same time as bucket completion, time bar volume is classified as buyer- or seller-initiated in probabilistic terms. Normal distribution is employed labelling as 'buy' the volume that results from multiplying the volume bar 
by the value of the normal distribution evaluated in the standardised price change $Z\left(\Delta P / \sigma_{\Delta P}\right)$. To standardise, we divide the corresponding price change by the standard deviation of all price changes for the whole sample. Analogously, we categorise as 'sell' the volume that results from multiplying the volume bar by the complementary of the normal distribution for the buy side, $1-Z\left(\Delta P / \sigma_{\Delta P}\right)$. Order imbalance $(O I)$ is then computed for each bucket simply by obtaining the absolute value of the difference between buy volume and sell volume in the assigned time bars.

3. VPIN and sample length Finally, in the last step we obtain VPIN values. To do this, it is necessary to define a new variable: sample length $(n)$. This variable establishes the number of the buckets with which VPIN is computed. Following the link between PIN and VPIN established in Easley et al. (2012),

$$
\begin{aligned}
V P I N & =\frac{\alpha \mu}{\alpha \mu+\varepsilon_{b}+\varepsilon_{s}} \approx \frac{E\left[V_{\tau}^{\text {Sell }}-V_{\tau}^{B u y}\right]}{E\left[V_{\tau}^{\text {Sell }}+V_{\tau}^{B u y}\right]} \\
& =\frac{\sum_{\tau=1}^{n} O I_{\tau}}{n^{*} V B S}
\end{aligned}
$$

where VPIN is simply the average of order imbalances in the sample length, that is, the result of dividing the sum of order imbalances for all the buckets in the sample length (proxy of the expected trade imbalance) by the product of volume bucket size (VBS) multiplied by the sample length $(n)$ (proxy for the expected total number of trades). the VPIN metric is updated after each volume bucket in a rolling-window process. For example, if the sample length is 50 , when bucket \#51 is filled, we drop bucket \#1 and we calculate the new VPIN based on buckets \#2 to \#51. Easley et al. (2012) first consider sample length equal to the number of buckets (50), but throughout the paper the authors change this variable to 350 or 250 depending on what they want to analyse. A sample length of 50 buckets when the number of buckets is also 50 is equivalent to obtaining a daily VPIN. A sample length of 250 (350) when the number of buckets is 50 is equivalent to obtaining a five-day (seven-day) VPIN. An annual VPIN is computed by averaging the values of the result VPIN series for each year. In this study, VPIN series are obtained using time bars of 1-minute. The volume bucket size (VBS) corresponds to the daily average trading volume (in shares) for each year. The sample length to obtain each VPIN observation is one volume bucket.

\section{Information asymmetry index (ASY)}

Finally, to isolate the common adverse selection component underlying our market microstructure proxies, we constructed an index of information asymmetry
(ASY) by employing principal components analysis. After computing the five measures of information asymmetry for each firm-year, the first (and only) factor with an eigenvalue greater than one explains $62.93 \%$ of the variance and each component of the asymmetry factor enters with positive sign, leading to the following index:

$$
\begin{aligned}
A S Y= & 0.510 Q D S P+0.277 A M H+0.468 P I \\
& +0.467 P I N+0.474 V P I N
\end{aligned}
$$

Therefore, each proxy for information asymmetry plays its role in the index. A higher value of the index means a higher level of adverse selection ${ }^{7}$.

\section{Research Design, Sample, and Data}

\section{Model specification}

We examine the effects of mandatory IFRS adoption on the level of information asymmetry among market participants. Specifically, we estimate the following regression model:

$$
\begin{aligned}
\text { ASYInf }_{i, t}= & \beta_{0}+\beta_{1} \text { IFRS }+\beta_{2} \text { Size }_{i, t}+\beta_{3} \text { Turnover }_{i, t} \\
& +\beta_{4} \text { Volat }_{i, t}+\beta_{5} \text { Lev }_{i, t}+\beta_{6} \text { Prof }_{i, t} \\
& +\beta_{7} \text { BTM }_{i, t}+\beta_{8} \text { Own }_{i, t}+\beta_{9} \text { Analys }_{i, t} \\
& +\beta_{10} \text { Ibex }_{i, t}+\sum_{j} \beta_{j} \text { Ind }+\varepsilon
\end{aligned}
$$

where $A S Y I n f_{i, t}$ is one of our six proxies for information asymmetry (QSPD, AMH, PI, PIN, VPIN and ASY) for firm $i$ in year $t$. IFRS is a dummy variable that takes the value 1 for the post adoption period (from 2005 to 2008) and 0 otherwise (from 2001 to 2004). We expect $\beta_{1}<0$ if after IFRS adoption information asymmetry is reduced. We include control variables according to the previous market microstructure and accounting literature. Thus, based on the extensive disclosure literature, it is expected that more transparent firms will present lower levels of information asymmetry. Following prior studies (e.g. Easley et al. 1996), we include firm size, share turnover and return variability, because the microstructure literature shows that larger, more frequently traded and less volatile firms are more liquid and suffer lower information asymmetry problems. Size is the natural logarithm of total sales. Turnover is the natural logarithm of trading volume (measured as the average daily volume in Euros) scaled by the market value of a firm's equity to facilitate cross-sectional comparison. Volat is a proxy for stock return volatility calculated as the standard deviation of daily returns. In addition, we control for firm 
Table 1 Descriptive statistics

\begin{tabular}{|c|c|c|c|c|c|c|}
\hline \multicolumn{7}{|c|}{ Panel A: Information asymmetry measures } \\
\hline & \#obs. & Mean & SD & $10^{\text {th }}$ percentile & Median & $90^{\text {th }}$ percentile \\
\hline QDSP & 504 & 0.0072 & 0.0071 & 0.0013 & 0.0046 & 0.0165 \\
\hline$A M H$ & 504 & 0.3543 & 2.0678 & 0.0005 & 0.0121 & 0.4410 \\
\hline$P l$ & 504 & 0.0041 & 0.0032 & 0.0011 & 0.0033 & 0.0086 \\
\hline PIN & 504 & 0.1964 & 0.0654 & 0.1241 & 0.1901 & 0.2738 \\
\hline VPIN & 504 & 0.2109 & 0.1270 & 0.0724 & 0.1828 & 0.3771 \\
\hline ASY & 504 & 0.0000 & 1.7739 & -1.9124 & -0.3586 & 2.2461 \\
\hline \multicolumn{7}{|c|}{ Panel B: Control variables } \\
\hline Size & 504 & 13.4755 & 1.9578 & 11.3499 & 13.4890 & 16.1361 \\
\hline Turnover & 504 & -6.2710 & 1.1701 & -7.7305 & -6.3064 & -4.9993 \\
\hline Volat & 504 & 1.9493 & 0.9324 & 1.0627 & 1.7105 & 3.2050 \\
\hline Lev & 504 & 0.6291 & 0.2340 & 0.3521 & 0.06395 & 0.8244 \\
\hline Prof & 504 & 0.0324 & 0.0880 & -0.0068 & 0.0384 & 0.0939 \\
\hline BTM & 504 & 0.6413 & 0.7581 & 0.2187 & 0.5802 & 1.2897 \\
\hline Own & 504 & 0.4715 & 0.2329 & 0.1510 & 0.4659 & 0.7602 \\
\hline Analys & 504 & 8.8294 & 7.5414 & 1 & 7 & 19 \\
\hline \multicolumn{7}{|c|}{ Panel C: Dichotomous variable } \\
\hline & \multicolumn{2}{|c|}{ \#obs. } & 0 & $\%$ & 1 & $\%$ \\
\hline IFRS & \multicolumn{2}{|c|}{504} & 252 & 50 & 252 & 50 \\
\hline Ibex & \multicolumn{2}{|c|}{504} & 351 & 69.64 & 153 & 30.36 \\
\hline
\end{tabular}

Notes: This table reports descriptive statistics on the variables of the present analysis. Panel A corresponds to information asymmetry metrics. QSPD is the relative quote bid-ask spread. AMH is the illiquidity measure of Amihud (2002). PI is the price impact measure proposed by Huang and Stoll (1996). PIN is Probability of Informed Trading based on the Easley et al. (1996) model. VPIN is Volume-synchronised Probability of Informed Trading developed in Easley et al. (2012). ASY is the composite index of information asymmetry based on the before market microstructure measures: QSPD, AMH, PI, PIN, and VPIN. Panel B contains control variables: Size is the natural logarithm of sales. Turnover is the natural logarithm of the average daily trading volume in $€$ scaled by market value of the firm's equity at the end of the year. Volat is the standard deviation of daily returns. Lev is the ratio of total debt to total assets. Prof is the return on assets. BTM is the book-to- market ratio. Own is the proportion of common shares held by the largest five shareholders. Analys is the total number of analysts following a firm. Panel $\mathrm{C}$ reports the frequency dummy variables. IFRS takes the value 1 for the post-adoption period and 0 for the pre-adoption period. Ibex is a dummy that takes the value 1 if the firm's stocks are constituents of the IBEX-35 and 0 otherwise.

characteristics, such as financial leverage, return on assets and growth options, because it is expected that firms with more financing needs, that are more profitable, and with more growth opportunities will have more incentives to be transparent and to disclose more information (e.g. Daske et al. 2013). Lev is the ratio of total debt to total assets, Prof is the return on assets, and BTM is the book-to-market ratio. We also include variables demonstrated by the prior literature to be associated with the quantity and quality of information disseminated by/about the firm and with its information environment, such as ownership concentration, financial analyst coverage and inclusion in a stock market index (e.g. Leuz 2003). A higher concentrated ownership is expected to be positively associated with information asymmetry because shareholders with large blocks are likely to have access to more private information about the firm. We use $O w n$ as a proxy for ownership concentration, which is the percentage of common shares held by the largest five shareholders of the company. Prior research also suggests that analyst coverage reduces the level of information asymmetry among market participants because the more analysts that follow a firm, the more information is gathered by intermediaries and investors and, therefore, the better the information environment of the firm. We include in our model the variable Analys, which represents the total number of analysts following a firm. Moreover, those firms with shares that are constituents of a stock market index are monitored with greater intensity by investors and market agents, thereby positively affecting the information environment of the firm. We include Ibex, which is a dummy variable taking the value of 1 if the company's share is a constituent of the IBEX$35,{ }^{8}$ and zero otherwise. Finally, we control for industry effects by including industry dummy variables, and for temporary effects using robust standard errors clustered by time and firm (Petersen 2009).

\section{Sample and data}

The sample is made up of stocks traded on the electronic trading platform of the Spanish Stock Exchange, known as the SIBE (Sistema de Interconexión Bursátil Español). The SIBE is an order-driven market where liquidity is provided by a limit order book. Trading is continuous from 9:00 a.m. to 5:30 p.m. There are two regular call auctions each day: the first determines the opening 


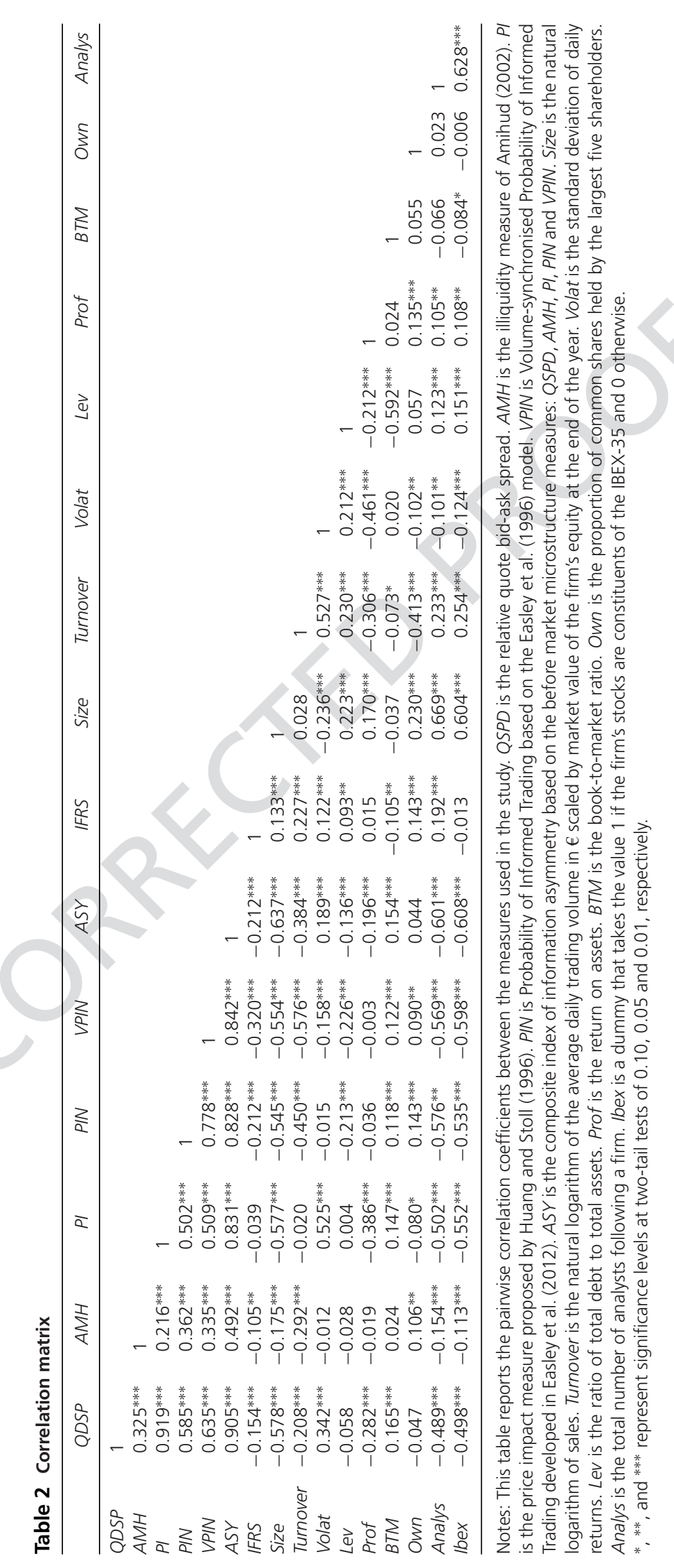


Table 3 Comparison between pre and post adoption period

\begin{tabular}{|c|c|c|c|c|c|c|c|c|c|}
\hline & \multicolumn{3}{|c|}{ Pre-adoption } & \multicolumn{3}{|c|}{ Post-adoption } & \multicolumn{3}{|c|}{ Difference } \\
\hline & \#obs. & Mean & SD & \#obs. & Mean & SD & Mean & t-stat & $z$-Wil \\
\hline QSPD & 63 & 0.008 & 0.006 & 63 & 0.006 & 0.007 & -0.002 & $-6.14^{* * *}$ & $-5.50^{* * *}$ \\
\hline$A M H$ & 63 & 0.572 & 2.218 & 63 & 0.137 & 0.492 & -0.435 & $-1.72 *$ & $-4.98^{* * *}$ \\
\hline PI & 63 & 0.004 & 0.003 & 63 & 0.004 & 0.003 & -0.000 & -1.49 & $-2.26^{* *}$ \\
\hline$P I N$ & 63 & 0.210 & 0.067 & 63 & 0.183 & 0.051 & -0.027 & $-5.45^{* * *}$ & $-4.93^{* * *}$ \\
\hline VPIN & 63 & 0.252 & 0.127 & 63 & 0.170 & 0.093 & -0.081 & $-10.15^{* * *}$ & $-6.83^{* * *}$ \\
\hline$A S Y$ & 63 & 0.376 & 1.781 & 63 & -0.376 & 1.441 & -0.753 & $-7.99^{* * *}$ & $-6.21^{* * *}$ \\
\hline Size & 63 & 13.216 & 2.032 & 63 & 13.735 & 1.814 & 0.520 & $5.14^{* * *}$ & $6.44^{* * *}$ \\
\hline Turnover & 63 & -6.537 & 0.996 & 63 & -6.005 & 1.097 & 0.531 & $7.19 * * *$ & $5.70 * * *$ \\
\hline Volat & 63 & 1.836 & 0.743 & 63 & 2.063 & 0.671 & 0.227 & $3.33^{* * *}$ & $3.34^{* * *}$ \\
\hline Lev & 63 & 0.607 & 0.174 & 63 & 0.651 & 0.194 & 0.044 & $2.01^{* *}$ & $2.13^{* *}$ \\
\hline Prof & 63 & 0.031 & 0.060 & 63 & 0.034 & 0.070 & 0.003 & 0.37 & 0.17 \\
\hline BTM & 63 & 0.721 & 0.415 & 63 & 0.562 & 0.517 & -0.159 & $-2.24^{* *}$ & $-2.69^{* * *}$ \\
\hline Own & 63 & 0.438 & 0.224 & 63 & 0.505 & 0.213 & 0.067 & $3.62^{* * *}$ & $3.95^{* * *}$ \\
\hline Analys & 63 & 7.381 & 5.345 & 63 & 10.278 & 8.127 & 2.897 & $4.95^{* * *}$ & $4.06^{* * *}$ \\
\hline
\end{tabular}

Notes: This table presents summary statistics of variables before and after IFRS adoption. The value of the difference before and after the adoption is also reported. QSPD is the relative quote bid-ask spread; AMH is the illiquidity measure of Amihud (2002). PI is the price impact measure proposed by Huang and Stoll (1996). PIN is Probability of Informed Trading based on the Easley et al. (1996) model. VPIN is Volume-synchronised Probability of Informed Trading developed in Easley et al. (2012). ASY is the composite index of information asymmetry based on the before market microstructure measures: QSPD, AMH, PI, PIN, and VPIN. Size is the natural logarithm of sales. Turnover is the natural logarithm of the average daily trading volume in $€$ scaled by market value of the firm's equity at the end of the year. Volat is the standard deviation of daily returns. Lev is the ratio of total debt to total assets. Prof is the return on assets. BTM is the book-to-market ratio. Own is the proportion of common shares held by the largest five shareholders. Analys is the total number of analysts following a firm. Ibex is a dummy that takes the value 1 if the firm's stocks are constituents of the IBEX-35 and 0 otherwise. The $t$-test and Wilcoxon $z$ statistic ( $z$-Wil) are used to test the null hypothesis of no significant differences in each measure between two periods.

$*, * *$, and ${ }^{* * *}$ represent significance levels at two-tail tests of $0.10,0.05$, and 0.01 , respectively

price (8:30-9:00 a.m.), while the second sets the official closing price (5:30-5:35 p.m.). Traders can submit three basic types of orders: limit orders, market orders, and market-to-limit orders. When the market is open in continuous session, a trade occurs whenever an incoming order hits the quotes on the other side of the order book. Non-executed orders remain in the order book using a price-time priority rule. Unexecuted orders can be altered or cancelled at any time. Continuous trading can be temporally interrupted since a system of stockspecific intraday price limits and short-lived call auctions is implemented to handle unusual volatility levels. In all auctions (open, close and volatility) orders can be submitted, modified or cancelled, but no trades occur.

Trade and quote data for this study come from SM data files provided by the Sociedad de Bolsas, S.A. SM files comprise detailed time-stamped information about the first level of the limit order book for each stock listed on the SIBE. Any trade, order submission and cancellation affecting best prices in the book generates a new record. The distinction between buyer-initiated and seller-initiated trades is straightforward, without the need to use a classification algorithm. Firms' financial statements data were obtained from the SABI database, compiled by Bureau Van Dijk, and ownership concentration and analysts' data were collected from Thomson Reuters Eikon Datastream files.

Our initial sample consists of all the non-financial firms listed continuously on the main segment of the
SIBE during the period January 2001 to December 2008. We choose this sample period to get a balanced set of four years before (from 2001 to 2004) versus after (from 2005 to 2008) mandatory IFRS adoption. Within our sample period, 64 non-financial firms are traded during all the years, but we have not been able to collect market microstructure data for one of them. Hence, the final sample consists of a balanced panel of 63 firms and 504 firm-year observations, 252 observations for the period 2001-2004 and 252 for the period 2005-2008. On average, stocks included in our sample represent around $72 \%$ of the market capitalization and $82 \%$ of the trading volume of the Spanish non-financial firms listed on the SIBE within our sample period.

\section{Results}

\section{Descriptive statistics}

Table 1 presents the descriptive statistics for the study variables for the full period (2001-2008): mean, median, standard deviation, 10th percentile and 90th percentile for the continuous variables (Panels A and B) and frequency for dichotomous variables (Panel C). The mean (median) of QSPD is $0.72 \%(0.46 \%)$. With regard to $A M H$, its mean in our sample (0.35) is similar to that reported by Amihud (2002). The average (median) of price impact measure $(P I)$ is $0.41 \%(0.33 \%)$. Consistent 
Table 4 Information asymmetry effects of IFRS adoption, pre-adoption period 2001-2004, post-adoption period 2005-2008

\begin{tabular}{|c|c|c|c|c|c|c|}
\hline & \multicolumn{6}{|c|}{ DEPENDENT VARIABLES } \\
\hline & QDSP & $A M H$ & $P l$ & PIN & VPIN & $A S Y$ \\
\hline IFRS & $\begin{array}{l}-0.209^{* * *} \\
(-3.74)\end{array}$ & $\begin{array}{l}-0.566^{* * *} \\
(-3.80)\end{array}$ & $\begin{array}{l}-0.041 \\
(-0.93)\end{array}$ & $\begin{array}{l}-0.059^{*} \\
(-1.75)\end{array}$ & $\begin{array}{l}-0.238^{* * *} \\
(-3.47)\end{array}$ & $\begin{array}{l}-0.123^{* * *} \\
(3.67)\end{array}$ \\
\hline Size & $\begin{array}{l}-0.163^{* * *} \\
(-3.59)\end{array}$ & $\begin{array}{l}-0.648^{* * *} \\
(-6.10)\end{array}$ & $\begin{array}{l}-0.103^{* * *} \\
(-2.60)\end{array}$ & $\begin{array}{l}-0.052 * * * \\
(-3.39)\end{array}$ & $\begin{array}{l}-0.094^{* * *} \\
(-4.25)\end{array}$ & $\begin{array}{l}-0.106^{* * *} \\
(-3.81)\end{array}$ \\
\hline Turnover & $\begin{array}{l}-0.287^{* * * *} \\
(-8.10)\end{array}$ & $\begin{array}{l}-1.050^{* * *} \\
(-10.88)\end{array}$ & $\begin{array}{l}-0.155^{\text {*** }} \\
(-6.20)\end{array}$ & $\begin{array}{l}-0.071^{* * *} \\
(-4.01)\end{array}$ & $\begin{array}{l}-0.162^{* * *} \\
(-8.82)\end{array}$ & $\begin{array}{l}-0.171^{\text {*** }} \\
(-7.99)\end{array}$ \\
\hline Volat & $\begin{array}{l}0.336^{* * *} \\
(6.61)\end{array}$ & $\begin{array}{l}0.573^{* * *} \\
(7.55)\end{array}$ & $\begin{array}{l}0.357^{* * *} \\
(9.66)\end{array}$ & $\begin{array}{c}0.018 \\
(0.76)\end{array}$ & $\begin{array}{l}-0.065^{* * *} \\
(-2.88)\end{array}$ & $\begin{array}{l}0.123^{* * *} \\
(5.58)\end{array}$ \\
\hline Lev & $\begin{array}{l}0.483^{* *} \\
(2.17)\end{array}$ & $\begin{array}{l}1.547^{* * * *} \\
(3.56)\end{array}$ & $\begin{array}{l}0.308^{*} \\
(1.83)\end{array}$ & $\begin{array}{l}-0.026 \\
(-0.28)\end{array}$ & $\begin{array}{l}0.154 \\
(1.32)\end{array}$ & $\begin{array}{c}0.215 \\
(1.54)\end{array}$ \\
\hline Prof & $\begin{array}{l}-0.634 \\
(-0.88)\end{array}$ & $\begin{array}{l}-0.374 \\
(-0.28)\end{array}$ & $\begin{array}{l}-0.359 \\
(-0.65)\end{array}$ & $\begin{array}{l}-0.182 \\
(-0.75)\end{array}$ & $\begin{array}{l}-0.458 \\
(-1.36)\end{array}$ & $\begin{array}{l}-0.570 \\
(-1.22)\end{array}$ \\
\hline BTM & $\begin{array}{l}0.193^{* * *} \\
(3.12)\end{array}$ & $\begin{array}{l}0.531^{* * *} \\
(3.61)\end{array}$ & $\begin{array}{l}0.130^{* * *} \\
(2.67)\end{array}$ & $\begin{array}{c}0.012 \\
(0.47)\end{array}$ & $\begin{array}{l}0.046 \\
(1.29)\end{array}$ & $\begin{array}{l}0.086^{* *} \\
(2.23)\end{array}$ \\
\hline Own & $\begin{array}{l}-0.039 \\
(-0.20)\end{array}$ & $\begin{array}{l}0.723^{*} \\
(1.91)\end{array}$ & $\begin{array}{c}0.004 \\
(0.02)\end{array}$ & $\begin{array}{l}0.228^{* * *} \\
(2.68)\end{array}$ & $\begin{array}{l}0.170 \\
(1.40)\end{array}$ & $\begin{array}{l}0.146 \\
(1.21)\end{array}$ \\
\hline Analys & $\begin{array}{l}-0.016^{* *} \\
(-2.33)\end{array}$ & $\begin{array}{l}-0.028^{*} \\
(-1.93)\end{array}$ & $\begin{array}{l}-0.014^{* * *} \\
(-2.57)\end{array}$ & $\begin{array}{l}-0.010^{* * *} \\
(-3.54)\end{array}$ & $\begin{array}{l}-0.013^{* *} \\
(-2.45)\end{array}$ & $\begin{array}{l}-0.016^{* * *} \\
(-3.02)\end{array}$ \\
\hline Ibex & $\begin{array}{l}-0.582^{* * *} \\
(-6.25)\end{array}$ & $\begin{array}{l}-1.223^{* * *} \\
(-4.93)\end{array}$ & $\begin{array}{l}-0.545^{* * *} \\
(-7.92)\end{array}$ & $\begin{array}{l}-0.106^{* * *} \\
(-2.69)\end{array}$ & $\begin{array}{l}-0.428^{* * *} \\
(-7.22)\end{array}$ & $\begin{array}{l}-0.354^{* * *} \\
(-7.19)\end{array}$ \\
\hline Intercept & $\begin{array}{l}-5.733^{* * *} \\
(-9.81)\end{array}$ & $\begin{array}{l}-4.501^{* * * *} \\
(-3.00)\end{array}$ & $\begin{array}{l}-6.234^{* * *} \\
(-12.02)\end{array}$ & $\begin{array}{l}-1.438^{* * *} \\
(-5.87)\end{array}$ & $\begin{array}{l}-1.337^{* * *} \\
(-4.01)\end{array}$ & $\begin{array}{l}1.020^{* * *} \\
(2.58)\end{array}$ \\
\hline $\begin{array}{l}\text { Indus. dum. } \\
R^{2}\end{array}$ & $\begin{array}{c}\text { Yes } \\
0.815\end{array}$ & $\begin{array}{l}\text { Yes } \\
0.879\end{array}$ & $\begin{array}{c}\text { Yes } \\
0.825\end{array}$ & $\begin{array}{c}\text { Yes } \\
0.641\end{array}$ & $\begin{array}{c}\text { Yes } \\
0.838\end{array}$ & $\begin{array}{c}\text { Yes } \\
0.830\end{array}$ \\
\hline \#obs. & 504 & 504 & 504 & 504 & 504 & 504 \\
\hline
\end{tabular}

Notes: This table reports OLS coefficients of the regression model (9) for the full period (from 2001 to 2008). QSPD is the relative quote bid-ask spread; $A M H$ is the illiquidity measure of Amihud (2002). PI is the price impact measure proposed by Huang and Stoll (1996). PIN is Probability of Informed Trading based on the Easley et al. (1996) model. VPIN is Volume-synchronised Probability of Informed Trading developed in Easley et al. (2012). ASY is the composite index of information asymmetry based on the before market microstructure measures: QSPD, AMH, PI, PIN, and VPIN. All microstructure measures are included in natural logarithms. IFRS is a dummy that takes the value 1 for the post-adoption period (2005-2008) and 0 for the pre-adoption period (2001-2004). Size is the natural logarithm of sales. Turnover is the natural logarithm of the average daily trading volume in $€$ scaled by market value of the firm's equity at the end of the year. Volat is the standard deviation of daily returns. Lev is the ratio of total debt to total assets. Prof is the return on assets. BTM is the book-to-market ratio. Own is the proportion of common shares held by the largest five shareholders. Analys is the total number of analysts following a firm. Ibex is a dummy that takes the value 1 if the firm's stocks are constituents of the IBEX-35 and 0 otherwise. Robust $t$ statistics clustered at the firm-year level in brackets.

$*, * *$, and ${ }^{* * *}$ represent significance levels at two-tail tests of $0.10,0.05$, and 0.01 , respectively.

with Abad and Yagüe (2012), the PIN and the VPIN show similar mean values, around $20 \%$ and $21 \%$, respectively. PIN values are also consistent with those reported in other studies using this information asymmetry proxy (e.g. Easley et al. 2002; Brown and Hillegeist 2007). The mean of $A S Y$ is zero (by construction) and its median is -0.36 . The statistical distributions of the above variables show that there are clear differences in the degree of asymmetric information among the firms in our sample. The control variables also show a significant level of dispersion in their values, reflecting the heterogeneity of our firm-year sample.

Table 2 provides the Pearson correlation matrix between the variables used in the study. All the information asymmetry proxies are positively correlated with each other, which indicates that these measures are likely to be driven by adverse selection, but each contains unique information. Moreover, the index is positively and significantly correlated with each information asymmetry variable, ranging from a correlation of $91 \%$ between $A S Y$ and $Q S P D$ to a correlation of $49 \%$ between $A S Y$ and $A M H$. Moreover, correlations between the index and the five proxies for information asymmetry are generally higher than correlations between the five proxies. This suggests that the index is a parsimonious way of measuring information asymmetry. The correlations between information asymmetry proxies and control variables are quite significant.

\section{Univariate analysis}

We begin our analysis with univariate comparisons of the measures of information asymmetry before and after IFRS adoption. In Table 3 we report summary statistics of our variables for both periods, the difference of means, 
Table 5 Information asymmetry effects of IFRS adoption, pre-adoption period 2001-2003, post-adoption period 2005-2008

\begin{tabular}{|c|c|c|c|c|c|c|}
\hline & \multicolumn{6}{|c|}{ DEPENDENT VARIABLES } \\
\hline & QDSP & $A M H$ & $P I$ & PIN & VPIN & ASY \\
\hline IFRS & $\begin{array}{l}-0.235^{* * *} \\
(-3.49)\end{array}$ & $\begin{array}{l}-0.667^{* * *} \\
(-4.77)\end{array}$ & $\begin{array}{l}-0.065 \\
(-1.32)\end{array}$ & $\begin{array}{l}-0.079^{* *} \\
(-2.43)\end{array}$ & $\begin{array}{l}-0.259^{* * *} \\
(-3.74)\end{array}$ & $\begin{array}{l}-0.144^{* * *} \\
(-4.06)\end{array}$ \\
\hline Size & $\begin{array}{l}-0.167^{* * *} \\
(-3.69)\end{array}$ & $\begin{array}{l}0.644^{* * *} \\
(-6.05)\end{array}$ & $\begin{array}{l}-0.105^{* * *} \\
(-2.58)\end{array}$ & $\begin{array}{l}-0.050^{* * *} \\
(-3.47)\end{array}$ & $\begin{array}{l}-0.098^{* * *} \\
(-4.30)\end{array}$ & $\begin{array}{l}-0.109^{* * *} \\
(-3.93)\end{array}$ \\
\hline Turnover & $\begin{array}{l}-0.285^{* * *} \\
(-7.65)\end{array}$ & $\begin{array}{l}-1.025^{* * *} \\
(-11.54)\end{array}$ & $\begin{array}{l}-0.152^{* * *} \\
(-5.63)\end{array}$ & $\begin{array}{l}-0.066^{* * *} \\
(-3.84)\end{array}$ & $\begin{array}{l}-0.159^{* * *} \\
(-7.86)\end{array}$ & $\begin{array}{l}-0.164^{* * *} \\
(-8.12)\end{array}$ \\
\hline Volat & $\begin{array}{l}0.306^{* * *} \\
(5.82)\end{array}$ & $\begin{array}{l}0.522^{* * *} \\
(7.71)\end{array}$ & $\begin{array}{l}0.335^{* * *} \\
(9.47)\end{array}$ & $\begin{array}{c}0.007 \\
(0.34)\end{array}$ & $\begin{array}{l}-0.078^{* * *} \\
(-4.27)\end{array}$ & $\begin{array}{l}0.104^{* * *} \\
(6.88)\end{array}$ \\
\hline Lev & $\begin{array}{l}0.528^{* *} \\
(2.20)\end{array}$ & $\begin{array}{l}1.521^{\text {**** }} \\
(3.33)\end{array}$ & $\begin{array}{l}0.340^{*} \\
(1.87)\end{array}$ & $\begin{array}{l}-0.033 \\
(-0.35)\end{array}$ & $\begin{array}{l}0.147 \\
(1.11)\end{array}$ & $\begin{array}{c}0.230 \\
(1.53)\end{array}$ \\
\hline Prof & $\begin{array}{l}-0.611 \\
(-0.86)\end{array}$ & $\begin{array}{l}-0.438 \\
(-0.34)\end{array}$ & $\begin{array}{l}-0.372 \\
(-0.68)\end{array}$ & $\begin{array}{l}-0.206 \\
(-0.89)\end{array}$ & $\begin{array}{l}-0.479 \\
(-1.43)\end{array}$ & $\begin{array}{l}-0.575 \\
(-1.25)\end{array}$ \\
\hline BTM & $\begin{array}{l}0.196^{* * *} \\
(3.33)\end{array}$ & $\begin{array}{l}0.504^{* * *} \\
(3.72)\end{array}$ & $\begin{array}{l}0.131^{* * *} \\
(2.85)\end{array}$ & $\begin{array}{c}0.007 \\
(0.28)\end{array}$ & $\begin{array}{c}0.039 \\
(1.08)\end{array}$ & $\begin{array}{l}0.085^{* *} \\
(2.31)\end{array}$ \\
\hline Own & $\begin{array}{c}0.003 \\
(0.02)\end{array}$ & $\begin{array}{c}0.762 \\
(1.91)\end{array}$ & $\begin{array}{c}0.015 \\
(0.09)\end{array}$ & $\begin{array}{l}0.226^{* * *} \\
(2.60)\end{array}$ & $\begin{array}{c}0.165 \\
(1.21)\end{array}$ & $\begin{array}{c}0.153 \\
(1.17)\end{array}$ \\
\hline Analys & $\begin{array}{l}-0.016^{* *} \\
(-2.28)\end{array}$ & $\begin{array}{l}-0.026^{*} \\
(-1.78)\end{array}$ & $\begin{array}{l}-0.014^{* *} \\
(-2.48)\end{array}$ & $\begin{array}{l}-0.010^{* * *} \\
(-3.47)\end{array}$ & $\begin{array}{l}-0.013^{* *} \\
(-2.38)\end{array}$ & $\begin{array}{l}-0.016^{* * *} \\
(-2.92)\end{array}$ \\
\hline Ibex & $\begin{array}{l}-0.583^{* * *} \\
(-6.21)\end{array}$ & $\begin{array}{l}-1.265^{* * *} \\
(-4.95)\end{array}$ & $\begin{array}{l}-0.554^{* * *} \\
(-8.00)\end{array}$ & $\begin{array}{l}-0.109^{* * *} \\
(-2.83)\end{array}$ & $\begin{array}{l}-0.419^{* * *} \\
(-6.48)\end{array}$ & $\begin{array}{l}-0.356^{* * *} \\
(-7.76)\end{array}$ \\
\hline Intercept & $\begin{array}{l}-5.636^{* * *} \\
(-9.83)\end{array}$ & $\begin{array}{l}-4.198^{* * *} \\
(-2.84)\end{array}$ & $\begin{array}{l}-6.134^{* * *} \\
(-11.70)\end{array}$ & $\begin{array}{l}-1.386^{* * *} \\
(-6.14)\end{array}$ & $\begin{array}{l}-1.209^{* * *} \\
(-3.71)\end{array}$ & $\begin{array}{l}1.135^{* * *} \\
(3.08)\end{array}$ \\
\hline $\begin{array}{l}\text { Indus. dum. } \\
R^{2}\end{array}$ & $\begin{array}{c}\text { Yes } \\
0.814\end{array}$ & $\begin{array}{l}\text { Yes } \\
0.878\end{array}$ & $\begin{array}{c}\text { Yes } \\
0.819\end{array}$ & $\begin{array}{c}\text { Yes } \\
0.648\end{array}$ & $\begin{array}{c}\text { Yes } \\
0.839\end{array}$ & $\begin{array}{c}\text { Yes } \\
0.833\end{array}$ \\
\hline \#obs. & 441 & 441 & 441 & 441 & 441 & 441 \\
\hline
\end{tabular}

Notes: This table reports OLS coefficients of the regression model (9) for the full period, excluding 2004. QSPD is the relative quote bid-ask spread; $A M H$ is the illiquidity measure of Amihud (2002). PI is the price impact measure proposed by Huang and Stoll (1996). PIN is Probability of Informed Trading based on the Easley et al. (1996) model. VPIN is Volume-synchronised Probability of Informed Trading developed in Easley et al. (2012). ASY is the composite index of information asymmetry based on the before market microstructure measures: QSPD, AMH, PI, PIN, and VPIN. All microstructure measures are included in natural logarithms. IFRS is a dummy that takes the value of 1 for the post-adoption period (2005-2008) and 0 for the pre-adoption period (2001-2003). Size is the natural logarithm of sales. Turnover is the natural logarithm of the average daily trading volume in $€$ scaled by market value of the firm's equity at the end of the year. Volat is the standard deviation of daily returns. Lev is the ratio of total debt to total assets. Prof is the return on assets. BTM is the book-to-market ratio. Own is the proportion of common shares held by the largest five shareholders. Analys is the total number of analysts following a firm. Ibex is a dummy that takes the value 1 if the firm's stocks are constituents of the IBEX-35 and 0 otherwise. Robust $t$ statistics clustered at the firm-year level in brackets.

$*, * *$, and ${ }^{* * *}$ represent significance levels at two-tail tests of $0.10,0.05$, and 0.01 , respectively.

and the paired $t$-test and Wilcoxon test ( $z$-statistic) values to check the null hypothesis of no significant differences between both periods.

Focusing on information asymmetry, we observe a reduction after IFRS adoption for all proxies estimated, which is significant at conventional levels using both parametric and non-parametric tests (with the only exception being $P I$ in the case of the $t$-test). This finding is consistent with the hypothesis that the higher disclosure and information comparability enhanced by IFRS implementation is associated with a reduction in information asymmetry, even in a country where the level of enforcement is not high. Regarding the changes in our control variables, we find increases in almost all of them according to the parametrical $t$-test and nonparametrical test of Wilcoxon at the $1 \%$ significance level (except in leverage, significant at the 5\% level). In $B T M$, inverse of growth opportunities, we show a reduction after IFRS, consistent with an increase in growth options, at the 5\% (1\%) significance level for $t$-test ( $z$ test). Only for Profdo we not find evidence of a significant change.

\section{Multivariate regression}

Table 4 presents the results of the multivariate regression analyses for Eq. (9) for the different information asymmetry proxies ( QSPD, AMH, PI, PIN, VPIN and $A S Y$ ) used as dependent variables. We report the coefficients and $t$-statistics based on standard errors doubleclustered by firm and year (Petersen 2009), which are robust to both heteroscedasticity and within firm serial correlation.

Our results show that the coefficient on IFRS is negative and statistically significant at the $1 \%$ level in four out of our six measures and at the $10 \%$ level in one of them. These findings give evidence of a reduction of 
Table 6 Information asymmetry effects of IFRS adoption, pre-adoption period 2001-2004, post-adoption period 2006-2008

\begin{tabular}{|c|c|c|c|c|c|c|}
\hline & \multicolumn{6}{|c|}{ DEPENDENT VARIABLES } \\
\hline & QDSP & $A M H$ & $P l$ & PIN & VPIN & $A S Y$ \\
\hline IFRS & $\begin{array}{l}-0.180^{* * *} \\
(-2.61)\end{array}$ & $\begin{array}{l}-0.604^{* * *} \\
(-3.35)\end{array}$ & $\begin{array}{l}-0.022 \\
(-0.041)\end{array}$ & $\begin{array}{l}-0.074^{*} \\
(-1.95)\end{array}$ & $\begin{array}{l}-0.304^{* * *} \\
(-4.81)\end{array}$ & $\begin{array}{l}-0.137^{* * *} \\
(-3.23)\end{array}$ \\
\hline Size & $\begin{array}{l}-0.165^{* * *} \\
(-3.53)\end{array}$ & $\begin{array}{l}-0.639^{* * * *} \\
(-5.85)\end{array}$ & $\begin{array}{l}-0.102^{* *} \\
(-2.53)\end{array}$ & $\begin{array}{l}-0.052^{* * *} \\
(-3.34)\end{array}$ & $\begin{array}{l}-0.093^{* * *} \\
(-3.91)\end{array}$ & $\begin{array}{l}-0.107^{* * *} \\
(-3.71)\end{array}$ \\
\hline Turnover & $\begin{array}{l}-0.289^{* * *} \\
(-9.23)\end{array}$ & $\begin{array}{l}-1.034^{* * *} \\
(-10.91)\end{array}$ & $\begin{array}{l}-0.156^{* * *} \\
(-7.05)\end{array}$ & $\begin{array}{l}-0.078^{* * *} \\
(-4.95)\end{array}$ & $\begin{array}{l}-0.156^{* * *} \\
(-10.69)\end{array}$ & $\begin{array}{l}-0.173^{* * *} \\
(-8.67)\end{array}$ \\
\hline Volat & $\begin{array}{l}0.317^{* * *} \\
(6.48)\end{array}$ & $\begin{array}{l}0.579^{* * *} \\
(6.67)\end{array}$ & $\begin{array}{l}0351^{* * * *} \\
\quad(9.07)\end{array}$ & $\begin{array}{c}0.015 \\
(0.65)\end{array}$ & $\begin{array}{l}-0.057^{* *} \\
(-2.21)\end{array}$ & $\begin{array}{l}0.119^{* * *} \\
(4.82)\end{array}$ \\
\hline Lev & $\begin{array}{l}0.520^{* *} \\
(2.33)\end{array}$ & $\begin{array}{l}1.541^{\text {**** }} \\
(3.72)\end{array}$ & $\begin{array}{l}0.308^{*} \\
(1.74)\end{array}$ & $\begin{array}{l}-0.017 \\
(-0.19)\end{array}$ & $\begin{array}{l}0.189^{*} \\
(1.68)\end{array}$ & $\begin{array}{l}0.240^{*} \\
(1.74)\end{array}$ \\
\hline Prof & $\begin{array}{l}-0.664 \\
(-0.91)\end{array}$ & $\begin{array}{l}-0.357 \\
(-0.28)\end{array}$ & $\begin{array}{l}-0.320 \\
(-0.56)\end{array}$ & $\begin{array}{l}-0.236 \\
(-0.98)\end{array}$ & $\begin{array}{l}-0.454 \\
(-1.40)\end{array}$ & $\begin{array}{l}-0.597 \\
(-1.23)\end{array}$ \\
\hline BTM & $\begin{array}{l}0.194^{* * *} \\
(3.18)\end{array}$ & $\begin{array}{l}0.511^{\text {*** }} \\
(3.63)\end{array}$ & $\begin{array}{l}0.125^{* *} \\
(2.55)\end{array}$ & $\begin{array}{c}0.013 \\
(0.54)\end{array}$ & $\begin{array}{c}0.050 \\
(1.53)\end{array}$ & $\begin{array}{l}0.088^{* *} \\
(2.36)\end{array}$ \\
\hline Own & $\begin{array}{l}-0.054 \\
(-0.26)\end{array}$ & $\begin{array}{l}0.765^{*} \\
(1.95)\end{array}$ & $\begin{array}{l}-0.012 \\
(-0.08)\end{array}$ & $\begin{array}{l}0.248^{* * *} \\
(3.13)\end{array}$ & $\begin{array}{l}0.219^{*} \\
(1.92)\end{array}$ & $\begin{array}{c}0.159 \\
(1.31)\end{array}$ \\
\hline Analys & $\begin{array}{l}-0.162^{* *} \\
(-2.24)\end{array}$ & $\begin{array}{l}-0.026^{*} \\
(-1.80)\end{array}$ & $\begin{array}{l}-0.014^{* *} \\
(-2.45)\end{array}$ & $\begin{array}{l}-0.009^{* * *} \\
(-3.13)\end{array}$ & $\begin{array}{l}-0.009^{* *} \\
(-2.16)\end{array}$ & $\begin{array}{l}-0.015^{\text {*** }} \\
(-2.71)\end{array}$ \\
\hline Ibex & $\begin{array}{l}-0.567^{* * *} \\
(-6.12)\end{array}$ & $\begin{array}{l}-1.288^{* * *} \\
(-5.23)\end{array}$ & $\begin{array}{l}-0.554^{* * *} \\
(-8.40)\end{array}$ & $\begin{array}{l}-0.095^{* *} \\
(-2.32)\end{array}$ & $\begin{array}{l}-0.453^{* * *} \\
(-7.53)\end{array}$ & $\begin{array}{l}-0.357^{\text {*** }} \\
(-7.18)\end{array}$ \\
\hline Intercept & $\begin{array}{l}-5.713^{* * *} \\
(-9.80)\end{array}$ & $\begin{array}{l}-4.533^{* * *} \\
(-2.88)\end{array}$ & $\begin{array}{l}-6.233^{* * *} \\
(-12.02)\end{array}$ & $\begin{array}{l}-1.493^{* * *} \\
(-6.21)\end{array}$ & $\begin{array}{l}-1.391^{* * *} \\
(-3.90)\end{array}$ & $\begin{array}{l}0.996^{* *} \\
(2.41)\end{array}$ \\
\hline $\begin{array}{l}\text { Indus. dum. } \\
R^{2}\end{array}$ & $\begin{array}{c}\text { Yes } \\
0.808\end{array}$ & $\begin{array}{l}\text { Yes } \\
0.876\end{array}$ & $\begin{array}{l}\text { Yes } \\
0.820\end{array}$ & $\begin{array}{c}\text { Yes } \\
0.638\end{array}$ & $\begin{array}{l}\text { Yes } \\
0.846\end{array}$ & $\begin{array}{c}\text { Yes } \\
0.824\end{array}$ \\
\hline \#obs. & 441 & 441 & 441 & 441 & 441 & 441 \\
\hline
\end{tabular}

Notes: This table reports OLS coefficients of the regression model (9) for the full period, excluding 2005. QSPD is the relative quote bid-ask spread; $A M H$ is the illiquidity measure of Amihud (2002). PI is the price impact measure proposed by Huang and Stoll (1996). PIN is Probability of Informed Trading based on the Easley et al. (1996) model. VPIN is Volume-synchronised Probability of Informed Trading developed in Easley et al. (2012). ASY is the composite index of information asymmetry based on the before market microstructure measures: QSPD, AMH, PI, PIN, and VPIN. All microstructure measures are included in natural logarithms. IFRS is a dummy that takes the value 1 for the post-adoption period (2006-2008) and 0 for the pre-adoption period (2001-2004). Size is the natural logarithm of sales. Turnover is the natural logarithm of the average daily trading volume in $€$ scaled by market value of the firm's equity at the end of the year. Volat is the standard deviation of daily returns. Lev is the ratio of total debt to total assets. Prof is the return on assets. BTM is the book-to-market ratio. Own is the proportion of common shares held by the largest five shareholders. Analys is the total number of analysts following a firm. Ibex is a dummy that takes the value 1 if the firm's stocks are constituents of the IBEX-35 and 0 otherwise. Robust $t$ statistics clustered at the firm-year level in brackets.

$*, * *$, and ${ }^{* * *}$ represent significance levels at two-tail tests of $0.10,0.05$, and 0.01 , respectively.

information asymmetry after IFRS adoption. We find a decrease of the bid-ask spread, illiquidity, PIN and VPIN after IFRS, while we do not find a significant effect on PI. In the last column, we confirm that there is a reduction of information asymmetry after IFRS, measured by the composite index that includes all the prior proxies (ASY). This finding is consistent with previous research that, on average, has found capital market benefits after the implementation of the new accounting standards. However, we find these post-IFRS benefits in terms of liquidity and adverse selection in a country where legal enforcement is weak, whereas previous studies with international samples find market capital benefits mostly in the aggregate of countries with strong enforcement systems (e.g. Daske et al. 2008; Li 2010). We also add to the previous literature the benefits of IFRS for adverse selection, measured by PIN and VPIN, not examined in previous literature. Our findings are consistent with previous research in Spain, which has found that IFRS disclosures to adjust SAS are priced by the market (Aledo et al. 2014).

All the coefficients of the control variables of market microstructure (firm size, turnover and volatility) present the expected signs according to the literature and are statistically significant at the $1 \%$ level. We find that more traded and larger firms show less information asymmetry, whereas firms with more volatile stock returns are associated with higher information asymmetry. Besides, we also find that both higher analyst following and the inclusion in the index IBEX-35 are associated with lower information asymmetry.

Overall, in a country with significant differences between the previous local GAAP and IFRS and a low enforcement level, our findings show that, after controlling for market determinants of adverse selection and the information environment of the firms, IFRS adoption is 
Table 7 Information asymmetry effects of IFRS adoption pre-adoption period, 2001-2003, post-adoption period 2006-2008

\begin{tabular}{|c|c|c|c|c|c|c|}
\hline & \multicolumn{6}{|c|}{ DEPENDENT VARIABLES } \\
\hline & QDSP & $A M H$ & $P l$ & PIN & VPIN & $A S Y$ \\
\hline IFRS & $\begin{array}{l}-0.200^{* *} \\
(-2.36)\end{array}$ & $\begin{array}{l}-0.702^{\text {*** }} \\
(-3.84)\end{array}$ & $\begin{array}{l}-0.041 \\
(-0.69)\end{array}$ & $\begin{array}{l}-0.091^{* *} \\
(-2.54)\end{array}$ & $\begin{array}{l}-0.321^{* * *} \\
(-4.85)\end{array}$ & $\begin{array}{l}-0.155^{* * *} \\
(-3.19)\end{array}$ \\
\hline Size & $\begin{array}{l}-0.169^{* * * *} \\
(-3.62)\end{array}$ & $\begin{array}{l}-0.633^{* * *} \\
(-5.77)\end{array}$ & $\begin{array}{l}-0.104^{* *} \\
(-2.48)\end{array}$ & $\begin{array}{l}-0.050^{* * *} \\
(-3.41)\end{array}$ & $\begin{array}{l}-0.097^{* * *} \\
(-3.89)\end{array}$ & $\begin{array}{l}-0.110^{* * *} \\
(-3.79)\end{array}$ \\
\hline Turnover & $\begin{array}{l}-0.290^{\text {**** }} \\
(-9.23)\end{array}$ & $\begin{array}{l}-1.004^{* * *} \\
(-11.70)\end{array}$ & $\begin{array}{l}-0.153^{* * *} \\
(-6.58)\end{array}$ & $\begin{array}{l}-0.074^{* * *} \\
(-5.02)\end{array}$ & $\begin{array}{l}-0.152^{* * *} \\
(-9.16)\end{array}$ & $\begin{array}{l}-0.168^{* * *} \\
(-9.02)\end{array}$ \\
\hline Volat & $\begin{array}{l}0.280^{* * * *} \\
(6.34)\end{array}$ & $\begin{array}{l}0.519^{* * *} \\
(7.03)\end{array}$ & $\begin{array}{l}0.323^{* * *} \\
(9.68)\end{array}$ & $\begin{array}{c}0.002 \\
(0.10)\end{array}$ & $\begin{array}{l}-0.073^{* * *} \\
(-3.44)\end{array}$ & $\begin{array}{l}0.096^{* * *} \\
(7.38)\end{array}$ \\
\hline Lev & $\begin{array}{l}0.574^{* *} \\
(2.35)\end{array}$ & $\begin{array}{l}1.507^{* * *} \\
(3.45)\end{array}$ & $\begin{array}{l}0.342^{*} \\
(1.76)\end{array}$ & $\begin{array}{l}-0.025 \\
(-0.28)\end{array}$ & $\begin{array}{c}0.183 \\
(1.40)\end{array}$ & $\begin{array}{l}0.258^{*} \\
(1.72)\end{array}$ \\
\hline Prof & $\begin{array}{l}-0.676 \\
(-0.96)\end{array}$ & $\begin{array}{l}-0.463 \\
(-0.38)\end{array}$ & $\begin{array}{l}-0.350 \\
(-0.63)\end{array}$ & $\begin{array}{l}-0.279 \\
(-1.28)\end{array}$ & $\begin{array}{l}-0.483 \\
(-1.51)\end{array}$ & $\begin{array}{l}-0.619 \\
(-1.32)\end{array}$ \\
\hline BTM & $\begin{array}{l}0.199^{* * *} \\
(3.39)\end{array}$ & $\begin{array}{l}0.482^{* * *} \\
(3.78)\end{array}$ & $\begin{array}{l}0.125^{* * *} \\
(2.67)\end{array}$ & $\begin{array}{l}0.008 \\
(0.33)\end{array}$ & $\begin{array}{l}0.044 \\
(1.29)\end{array}$ & $\begin{array}{l}0.088^{* *} \\
(2.44)\end{array}$ \\
\hline Own & $\begin{array}{l}-0.012 \\
(-0.06)\end{array}$ & $\begin{array}{l}0.811^{*} \\
(1.92)\end{array}$ & $\begin{array}{l}-0.004 \\
(-0.02)\end{array}$ & $\begin{array}{l}0.247^{* * * *} \\
(3.05)\end{array}$ & $\begin{array}{l}0.218 \\
(1.62)\end{array}$ & $\begin{array}{c}0.166 \\
(1.23)\end{array}$ \\
\hline Analys & $\begin{array}{l}-0.016^{* *} \\
(-2.18)\end{array}$ & $\begin{array}{l}-0.024^{*} \\
(-1.65)\end{array}$ & $\begin{array}{l}-0.014^{* *} \\
(-2.37)\end{array}$ & $\begin{array}{l}-0.009^{* * *} \\
(-2.95)\end{array}$ & $\begin{array}{l}-0.010^{* *} \\
(-2.06)\end{array}$ & $\begin{array}{l}-0.014^{* * *} \\
(-2.59)\end{array}$ \\
\hline Ibex & $\begin{array}{l}-0.559^{* * *} \\
(-6.03)\end{array}$ & $\begin{array}{l}-1.336^{* * *} \\
(-5.18)\end{array}$ & $\begin{array}{l}-0.563^{* * *} \\
(-8.28)\end{array}$ & $\begin{array}{l}-0.094^{* *} \\
(-2.41)\end{array}$ & $\begin{array}{l}-0.433^{* * *} \\
(-6.59)\end{array}$ & $\begin{array}{l}-0.356^{\text {*** }} \\
(-7.85)\end{array}$ \\
\hline Intercept & $\begin{array}{l}-5.625^{* * *} \\
(-9.96)\end{array}$ & $\begin{array}{l}-4.216^{* * * *} \\
(-2.72)\end{array}$ & $\begin{array}{l}-6.130^{* * * *} \\
(-11.73)\end{array}$ & $\begin{array}{l}-1.448^{* * *} \\
(-6.63)\end{array}$ & $\begin{array}{l}-1.257^{* * *} \\
(-3.51)\end{array}$ & $\begin{array}{l}1.113^{* * *} \\
(2.86)\end{array}$ \\
\hline $\begin{array}{l}\text { Indus. dum. } \\
R^{2}\end{array}$ & $\begin{array}{c}\text { Yes } \\
0.807\end{array}$ & $\begin{array}{l}\text { Yes } \\
0.875\end{array}$ & $\begin{array}{c}\text { Yes } \\
0.813\end{array}$ & $\begin{array}{c}\text { Yes } \\
0.647\end{array}$ & $\begin{array}{c}\text { Yes } \\
0.846\end{array}$ & $\begin{array}{c}\text { Yes } \\
0.826\end{array}$ \\
\hline \#obs. & 378 & 378 & 378 & 378 & 378 & 378 \\
\hline
\end{tabular}

Notes: This table reports OLS coefficients of the regression model (9) for the full period, excluding 2004 and 2005. QSPD is the relative quote bid-ask spread; $A M H$ is the illiquidity measure of Amihud (2002). PI is the price impact measure proposed by Huang and Stoll (1996). PIN is Probability of Informed Trading based on the Easley et al. (1996) model. VPIN is Volume-synchronised Probability of Informed Trading developed in Easley et al. (2012). ASY is the composite index of information asymmetry based on the before market microstructure measures: QSPD, AMH, PI, PIN, and VPIN. All microstructure measures are included in natural logarithms. IFRS is a dummy that takes the value 1 for the post-adoption period (2006-2008) and 0 for the pre-adoption period (2001-2003). Size is the natural logarithm of sales. Turnover is the natural logarithm of the average daily trading volume in $€$ scaled by market value of the firm's equity at the end of the year. Volat is the standard deviation of daily returns. Lev is the ratio of total debt to total assets. Prof is the return on assets. BTM is the book-to-market ratio. Own is the proportion of common shares held by the largest five shareholders. Analys is the total number of analysts following a firm. Ibex is a dummy that takes the value 1 if the firm's stocks are constituents of the IBEX-35 and 0 otherwise. Robust $t$ statistics clustered at the firm-year level in brackets.

$*, * *$, and ${ }^{* * *}$ represent significance levels at two-tail tests of $0.10,0.05$, and 0.01 , respectively.

associated with a reduction in the level of information asymmetry in the stock market. Thus, our findings support Barth and Israeli's (2013) point of view that IFRS adoption itself can confer capital-market benefits.

\section{Sensitivity analyses}

\section{Alternative year periods of analysis}

To assess the robustness of our results, we examine alternative periods to mitigate concerns that the findings may differ depending on the pre-post IFRS periods selected. First, like other listed firms within the European Union, Spanish firms were mandatorily required to prepare their financial statements from 1 January 2005. However, the IFRS adoption was preceded by a long introduction process and any firm could pre-empt the introduction of
IFRS. For this reason, we drop 2004 from our original sample period and repeat all analyses. The results, reported in Table 5, are robust to excluding this year. We again find for five out of our six proxies of information asymmetry a negative and significant effect of IFRS.

Furthermore, to avoid any potential impact that the first year of IFRS adoption may have on our results, for example, firms could disclose greater levels of information or be subject to higher control by investors and regulators, as suggested by Brochet et al. (2013, p. 1394), we exclude 2005 from the original analysis period. Table 6 reports the results once effects that may be attributable to the transition year are eliminated, and we find the results are similar to those reported above. We obtain the same results after dropping simultaneously the last year before and the first year of the mandatory IFRS adoption (2004-2005) to avoid the effects of 
Table 8 Firm-month analysis of information asymmetry effects around IFRS adoption

\begin{tabular}{|c|c|c|c|c|c|c|}
\hline & \multicolumn{6}{|c|}{ DEPENDENT VARIABLES } \\
\hline & QDSP & $A M H$ & $P l$ & PIN & VPIN & ASY \\
\hline IFRS & $\begin{array}{l}-0.102^{* *} \\
(-2.26)\end{array}$ & $\begin{array}{l}-0.220^{* * *} \\
(-2.76)\end{array}$ & $\begin{array}{c}0.032 \\
(0.99)\end{array}$ & $\begin{array}{c}0.015 \\
(0.54)\end{array}$ & $\begin{array}{l}-0.136^{* * *} \\
(-3.30)\end{array}$ & $\begin{array}{l}-0.046^{* *} \\
(-2.15)\end{array}$ \\
\hline Size & $\begin{array}{l}-0.110^{* * * *} \\
(-2.72)\end{array}$ & $\begin{array}{l}-0.430^{* * *} \\
(-3.31)\end{array}$ & $\begin{array}{l}-0.074^{* * *} \\
(-2.56)\end{array}$ & $\begin{array}{l}-0.031 \\
(-1.55)\end{array}$ & $\begin{array}{l}-0.036 \\
(-1.28)\end{array}$ & $\begin{array}{l}-0.046^{* *} \\
(-2.22)\end{array}$ \\
\hline Turnover & $\begin{array}{l}-0.249^{* * *} \\
(-7.78)\end{array}$ & $\begin{array}{l}-0.950^{* * *} \\
(-11.28)\end{array}$ & $\begin{array}{l}-0.099^{* * *} \\
(-3.34)\end{array}$ & $\begin{array}{l}-0.055^{* * *} \\
(-2.68)\end{array}$ & $\begin{array}{l}-0.077^{* * *} \\
(-3.63)\end{array}$ & $\begin{array}{l}-0.104^{* * *} \\
(-4.89)\end{array}$ \\
\hline Volat & $\begin{array}{l}0.225^{* * *} \\
(5.24)\end{array}$ & $\begin{array}{l}0.428^{* * *} \\
(4.57)\end{array}$ & $\begin{array}{l}0.308^{* * *} \\
(5.75)\end{array}$ & $\begin{array}{l}0.093^{* * *} \\
(6.36)\end{array}$ & $\begin{array}{l}0.047^{*} \\
(1.79)\end{array}$ & $\begin{array}{l}0.128^{* * *} \\
(5.94)\end{array}$ \\
\hline Lev & $\begin{array}{c}0.047 \\
(0.18)\end{array}$ & $\begin{array}{c}0.534 \\
(0.86)\end{array}$ & $\begin{array}{l}-0.009 \\
(-0.04)\end{array}$ & $\begin{array}{l}-0.107 \\
(-0.65)\end{array}$ & $\begin{array}{l}-0.296^{* *} \\
(-2.21)\end{array}$ & $\begin{array}{l}-0.066 \\
(-0.51)\end{array}$ \\
\hline Prof & $\begin{array}{l}-1.956^{* *} \\
(-2.56)\end{array}$ & $\begin{array}{l}-1.008 \\
(-0.56)\end{array}$ & $\begin{array}{l}-1.307^{* * *} \\
(-2.74)\end{array}$ & $\begin{array}{l}-0.063 \\
(-0.21)\end{array}$ & $\begin{array}{l}0.088 \\
(0.31)\end{array}$ & $\begin{array}{l}-0.747^{* *} \\
(-2.20)\end{array}$ \\
\hline BTM & $\begin{array}{l}0.209^{* *} \\
(2.02)\end{array}$ & $\begin{array}{l}0.588^{* *} \\
(2.17)\end{array}$ & $\begin{array}{l}0.176^{* *} \\
(2.05)\end{array}$ & $\begin{array}{c}0.059 \\
(1.12)\end{array}$ & $\begin{array}{l}0.063 \\
(1.00)\end{array}$ & $\begin{array}{l}0.101^{*} \\
(1.86)\end{array}$ \\
\hline Own & $\begin{array}{l}-0.139 \\
(-0.64)\end{array}$ & $\begin{array}{l}0.572 \\
(1.34)\end{array}$ & $\begin{array}{l}0.089 \\
(0.58)\end{array}$ & $\begin{array}{l}0.244^{* *} \\
(2.15)\end{array}$ & $\begin{array}{l}0.438^{* * * *} \\
(3.99)\end{array}$ & $\begin{array}{c}0.094 \\
(1.01)\end{array}$ \\
\hline Analys & $\begin{array}{l}-0.026^{* *} \\
(-2.42)\end{array}$ & $\begin{array}{l}-0.063^{* *} \\
(-2.33)\end{array}$ & $\begin{array}{l}-0.020^{* *} \\
(-2.52)\end{array}$ & $\begin{array}{l}-0.010^{*} \\
(-1.91)\end{array}$ & $\begin{array}{l}-0.011^{* *} \\
(-2.02)\end{array}$ & $\begin{array}{l}-0.013^{* *} \\
(-2.47)\end{array}$ \\
\hline Ibex & $\begin{array}{l}-0.620^{* * *} \\
(-5.21)\end{array}$ & $\begin{array}{l}-1.001^{* * *} \\
(-3.64)\end{array}$ & $\begin{array}{l}-0.483^{* * *} \\
(-5.35)\end{array}$ & $\begin{array}{l}-0.147^{* * *} \\
(-2.75)\end{array}$ & $\begin{array}{l}-0.423^{* * *} \\
(-6.33)\end{array}$ & $\begin{array}{l}-0.288^{* * *} \\
(-5.19)\end{array}$ \\
\hline Intercept & $\begin{array}{l}-5.792^{* * *} \\
(-11.22)\end{array}$ & $\begin{array}{l}-6.344^{* * *} \\
(-4.36)\end{array}$ & $\begin{array}{l}-6.117^{* * * *} \\
(-16.35)\end{array}$ & $\begin{array}{l}-1.820^{* * * *} \\
(-6.69)\end{array}$ & $\begin{array}{l}-1.886^{* * *} \\
(-5.00)\end{array}$ & $\begin{array}{l}0.772^{* * *} \\
(2.76)\end{array}$ \\
\hline $\begin{array}{l}\text { Indus. dum. } \\
R^{2}\end{array}$ & $\begin{array}{l}\text { Yes } \\
0.800\end{array}$ & $\begin{array}{l}\text { Yes } \\
0.876\end{array}$ & $\begin{array}{l}\text { Yes } \\
0.742\end{array}$ & $\begin{array}{c}\text { Yes } \\
0.305\end{array}$ & $\begin{array}{c}\text { Yes } \\
0.603\end{array}$ & $\begin{array}{c}\text { Yes } \\
0.745\end{array}$ \\
\hline \#obs. & 1884 & 1882 & 1882 & 1857 & 1882 & 1856 \\
\hline
\end{tabular}

Notes: This table reports OLS coefficients of the regression model (9) for fifteen months before and after IFRS adoption. QSPD is the relative quote bid-ask spread; $A M H$ is the illiquidity measure of Amihud (2002). PI is the price impact measure proposed by Huang and Stoll (1996). PIN is Probability of Informed Trading based on the Easley et al. (1996) model. VPIN is Volume-synchronised Probability of Informed Trading developed in Easley et al. (2012). ASY is the composite index of information asymmetry based on the before market microstructure measures: QSPD, PI, PIN, and VPIN. All microstructure measures are included in natural logarithms. IFRS is a dummy that takes the value 1 for the post-adoption period and 0 for the pre-adoption period. Size is the natural logarithm of sales. Turnover is the natural logarithm of the average daily trading volume in $€$ scaled by market value of the firm's equity at the end of the month. Volat is the monthly standard deviation of daily returns. Lev is the ratio of total debt to total assets. Prof is the return on assets. BTM is the book-to-market ratio. Own is the proportion of common shares held by the largest five shareholders. Analys is the total number of analysts following a firm. Ibex is a dummy that takes the value 1 the firm's stocks are constituents of the IBEX-35 and 0 otherwise. Robust $t$ statistics clustered at the firm and month-year levels in brackets.

$*, * *$, and ${ }^{* * *}$ represent significance levels at two-tail tests of $0.10,0.05$, and 0.01 , respectively.

this transaction period to IFRS (see Table 7). We also repeat the analyses removing those years farthest from the year of IFRS adoption to minimise the potential effects of the financial crisis: $2002-2004$ vs. 2005-2007; 2002-2004 vs. 2006-2007; 2002-2003 vs. 2006-2007. All the results (not tabulated) are robust. Finally, although in our regression estimations we control for temporal effects, to check once more that the improvements in information asymmetry observed after IFRS adoption are not a function of time we analyse changes in our information asymmetry measures in the years of the pre-IFRS period (e.g. 2003 vs. 2004). The (untabulated) results show that there are no improvements in information asymmetry prior to IFRS adoption. Therefore, all our findings suggest that the IFRS adoption is significantly associated with lower levels of information asymmetry and that it is not due to an improvement through time.

\section{Firm-month analyses around mandatory IFRS adoption}

In addition to the prior firm-year analyses, we collect monthly data for our information asymmetry proxies and repeat the same analyses around the time of IFRS adoption taking into account the early release of IFRS information through interim reports. Thus, we explicitly assess the sensitivity of our findings using another data frequency. We analyse a window of -15 and +15 months around the first interim report prepared under IFRS (March 2005), so it includes monthly data from January 2004 to June 2006 (Table 8). Focusing on this shorter time period around mandatory IFRS adoption, as Daske et al. (2008) point out, we could be capturing the effects of the relevant accounting change per se with less likelihood of capturing the effects of other institutional changes (e.g, in the governance or enforcement regimes). 
Table 9 Information asymmetry effects of IFRS adoption by firm size and ownership concentration

\begin{tabular}{|c|c|c|c|c|c|c|}
\hline & \multicolumn{3}{|c|}{ Panel A: Partition by firm size } & \multicolumn{3}{|c|}{ Panel B: Partition by ownership concentration } \\
\hline & Small & Large & Diff. & Low concentred & High concentred & Diff. \\
\hline IFRS & $\begin{array}{l}-0.115^{\text {*** }} \\
(-5.27)\end{array}$ & $\begin{array}{l}-0.124^{* *} \\
(-2.06)\end{array}$ & 0.009 & $\begin{array}{l}-0.082^{* *} \\
(-2.03)\end{array}$ & $\begin{array}{l}-0.154^{* *} \\
(-2.45)\end{array}$ & $0.072^{* *}$ \\
\hline Size & $\begin{array}{l}-0.078^{* * *} \\
(-2.46)\end{array}$ & $\begin{array}{l}-0.161^{* * *} \\
(-14.10)\end{array}$ & & $\begin{array}{l}-0.088^{* * *} \\
(-3.57)\end{array}$ & $\begin{array}{l}-0.145^{* * *} \\
(-4.60)\end{array}$ & \\
\hline Turnover & $\begin{array}{l}-0.177^{* * *} \\
(-7.52)\end{array}$ & $\begin{array}{l}-0.184^{* * *} \\
(-5.09)\end{array}$ & & $\begin{array}{l}-0.196^{* * *} \\
(-6.12)\end{array}$ & $\begin{array}{l}-0.183^{* * *} \\
(-6.88)\end{array}$ & \\
\hline Volat & $\begin{array}{l}0.139^{* * *} \\
(4.92)\end{array}$ & $\begin{array}{l}0.115^{* * *} \\
(2.93)\end{array}$ & & $\begin{array}{l}0.143^{* * *} \\
(7.14)\end{array}$ & $\begin{array}{l}0.119^{* * *} \\
(3.51)\end{array}$ & \\
\hline Lev & $\begin{array}{l}0.297^{*} \\
(1.86)\end{array}$ & $\begin{array}{l}-0.141 \\
(-0.97)\end{array}$ & & $\begin{array}{l}0.370 * * \\
(2.09)\end{array}$ & $\begin{array}{l}-0.173 \\
(-0.94)\end{array}$ & \\
\hline Prof & $\begin{array}{l}-0.253 \\
(-0.65)\end{array}$ & $\begin{array}{l}-1.830^{* * *} \\
(-3.33)\end{array}$ & & $\begin{array}{l}-0.321 \\
(-0.63)\end{array}$ & $\begin{array}{c}-1.116 \\
(1.60)\end{array}$ & \\
\hline BTM & $\begin{array}{l}0.092^{* *} \\
(2.39)\end{array}$ & $\begin{array}{c}0.097 \\
(1.27)\end{array}$ & & $\begin{array}{l}0.109^{* *} \\
(2.21)\end{array}$ & $\begin{array}{l}0.139^{* * *} \\
(2.91)\end{array}$ & \\
\hline Own & $\begin{array}{c}0.178 \\
(0.97)\end{array}$ & $\begin{array}{c}0.128 \\
(1.05)\end{array}$ & & $\begin{array}{l}0.665^{* * *} \\
(2.57)\end{array}$ & $\begin{array}{c}0.221 \\
(1.59)\end{array}$ & \\
\hline Analys & $\begin{array}{l}-0.014 \\
(-1.19)\end{array}$ & $\begin{array}{l}-0.011^{* *} \\
(-2.33)\end{array}$ & & $\begin{array}{l}-0.017^{* * *} \\
(-2.93)\end{array}$ & $\begin{array}{l}-0.008^{* *} \\
(-2.19)\end{array}$ & \\
\hline Ibex & $\begin{array}{l}-0.567^{* * *} \\
(-6.75)\end{array}$ & $\begin{array}{l}-0.269^{* * *} \\
(-4.18)\end{array}$ & & $\begin{array}{l}-0.496 * * * \\
(-7.13)\end{array}$ & $\begin{array}{l}-0.265^{* * *} \\
(-3.64)\end{array}$ & \\
\hline Intercept & $\begin{array}{l}0.687^{*} \\
(1.84)\end{array}$ & $\begin{array}{l}1.980^{* * *} \\
(5.36)\end{array}$ & & $\begin{array}{c}0.415 \\
(1.18)\end{array}$ & $\begin{array}{l}1.604^{* * *} \\
(3.26)\end{array}$ & \\
\hline Indus. dum. & Yes & Yes & & Yes & Yes & \\
\hline$R^{2}$ & 0.546 & 0.884 & & 0.855 & 0.857 & \\
\hline \#obs. & 252 & 252 & & 252 & 252 & \\
\hline
\end{tabular}

Notes: This table reports OLS coefficients of the regression model (9) for the full period by using as dependent variable ASY, which is the composite index of information asymmetry based on the market microstructure measures: QSPD, AMH, PI, PIN, and VPIN. IFRS is a dummy that takes the value 1 for the post-adoption period (2005-2008) and 0 for the pre-adoption period (2001-2004). Size is the natural logarithm of sales. Turnover is the natural logarithm of the average daily trading volume in $€$ scaled by market value of the firm's equity at the end of the year. Volat is the standard deviation of daily returns. Lev is the ratio of total debt to total assets. Prof is the return on assets. BTM is the book-to-market ratio. Own is the proportion of common shares held by the largest five shareholders. Analys is the total number of analysts following a firm. Ibex is a dummy that takes the value 1 if the firm's stocks are constituents of the IBEX-35 and 0 otherwise. Robust $t$ statistics clustered at the firm-year level in brackets.

$*, * *$, and ${ }^{* * *}$ represent significance levels at two-tail tests of $0.10,0.05$, and 0.01 , respectively.

As shown in Table 8, in four out of our six proxies of information asymmetry, there is a negative and significant effect of IFRS, suggesting that IFRS adoption is significantly associated with lower levels of information asymmetry. Our results (not tabulated) are also robust if we exclude the year 2005 in the analysis and thus analyse the period from October $2003(-15)$ to March 2007 (+15).

\section{Analyses of the effects of IFRS adoption for heterogeneous firms}

We provide additional evidence of the IFRS effects for firms characterised by different information environments. Since extensive research suggests that both firm size and ownership concentration proxy for the quantity and quality of information available about a firm, we divide our sample firms into big versus small firms and into those with high versus low ownership concentration according to the median values. Thus, we further investigate whether the effects of IFRS adoption on information asymmetry are different depending on the firm's information environment. Table 9 reports the results for the two firm partitions by size (Panel A) and by ownership concentration (Panel B), obtained using the composite index of asymmetric information (ASY) and the firmyear panel data of our sample period. As seen in Panel A, the coefficient on IFRS is significantly negative for both small and large firms presenting very similar values in both cases (coefficients equal to -0.115 and -0.124 , respectively). Focusing on the effects of IFRS depending on the firm's corporate governance environment, which we proxy for ownership concentration, as Panel B shows, the coefficient on IFRS is also negative and significantly negative different from zero for both those firms with low concentrated (coefficient $=-0.082, t$-statistic $=$ -2.03 ) and high concentrated ownership (coefficient $=$ $-0.154, t$-statistic $=-2.45$ ), however, it seems that the effect is stronger for more concentrated firms (the difference between coefficients on IFRS of both two firms' groups is statistically significant at the $5 \%$ level). This finding could suggest that IFRS adoption has implied 
a reduction of information asymmetries in those firms that are less proactive in disclosing information, thus advocating the benefits of IFRS and the argument that the benefits produced could be due to the higher disclosure requirements of IFRS.

\section{Conclusions}

This study examines the consequences of IFRS regarding information asymmetry in Spain, a country with significant differences between local GAAP and IFRS and low levels of enforcement. We use individual proxies for information asymmetry developed by market microstructure literature (i.e. relative quoted spread, illiquidity measure, price impact, PIN, and VPIN) and an adverse selection index combining all of them, which allows us to assess in a precise way the effect of IFRS on the level of adverse selection among market participants. Using annual and monthly data, we find a significant reduction of information asymmetry associated with mandatory IFRS adoption, which in a sensitivity analysis we find is higher for those firms with higher ownership concentration. Due to the Spanish features mentioned above and since the enforcement level has not substantially changed in this country after IFRS adoption, our results support the view that IFRS per se convey benefits to the market. Our findings are consistent with the argument that IFRS adoption implies an increase in financial reporting quality or disclosure and enhances financial information comparability.

Our study contributes to the literature on the consequences of IFRS adoption in the capital market and to the debate regarding which sources bring about market benefits after this adoption. Previous studies with international samples have found market benefits associated with IFRS adoption in terms of liquidity and cost of capital, particularly in countries with strong legal enforcement and in firms that have more reporting incentives (Daske et al. 2008, 2013; Li 2010). By focusing on a single country we avoid the heterogeneity of low enforcement countries, showing that even in this type of country IFRS adoption can be associated with positive economic consequences in the market. Nevertheless, we are cautious with regard to this argument, because, although we have controlled for market and firm characteristics and carried out several robustness tests, the reduction in the level of information asymmetry observed could be driven, besides the implementation of the new standards, by other economic factors that may have affected the firms' information environment.

\section{Acknowledgements}

David Abad acknowledges financial support from the Ministerio de Ciencia y Competitividad through grants
ECO2013-44409-P and ECO2014-58434-P. José Yagüe acknowledges financial support from Fundación Caja Murcia.

\section{Notes}

1 See Brüggemann et al. (2013) for a review.

2 In terms of market capitalisation and trading volume, the Spanish Stock Exchange is one of the largest stock markets for which IFRS was made mandatory in 2005 (see the 2006 World Federation of Exchanges annual report: http://www.worldexchanges.org/insight/reports/2006-wfe-annual-report).

3 Both bid-ask spread and illiquidity ratio are noisy proxies for asymmetric information given that they commonly include other components that are not related to information (inventory costs, order processing cost, monopoly rents, etc.), but that also influence stock liquidity.

4 We only report the results using 30-minute price impact. The results using 1 - and 5-minute price impactd are quite similar to those presented and they are available upon request from the authors.

5 We thank one reviewer for the suggestion of adopting the method of Gan et al. (2005) to set initial values. In the previous version, we used Yan and Zhang's (2012) procedure. Results present neither quantitative nor qualitative variations, but we have decided to use this method because it allows us to obtain more available estimations.

6 Easley et al. (1997) indicate that a 30 trading-day window allows sufficient trade observations for the PIN estimation procedure. Akay et al. (2012) use 20 trading days to estimate PIN, finding numerical solutions for all their estimations. Hence, the use of one-month transaction data should be wide enough to produce reliable estimates and also to allow us to obtain more PIN estimations as a result of being confronted with fewer computational problems.

7 In addition to estimating this index by employing the principal components analysis, we also estimate an equally weighted index from our information asymmetry measures. To do so, we standardise the individual proxies and calculate the mean of the five proxies. The results obtained with both indexes are very similar. We do not report the results obtained by using the equally weighted index, but they are available upon request from the authors.

8 The IBEX-35 is the official index of the Spanish Stock Exchange, composed of the 35 most liquid and active stocks listed on the Spanish Stock Exchange.

\section{References}

Abad, D. and Yagüe, J. 2012, 'From PIN to VPIN: An Introduction to Order Flow Toxicity', The Spanish Review of Financial Economics, 10 (2): 74-83.

Akay, O., Cyree, H.B. Griffiths, M.D. and Winters, D.B. 2012, 'What Does PIN Identify? Evidence from the T-bill Market', Journal of Financial Markets, 15 (1): 29-46.

Aledo Martínez, J., Abellán Martínez, D. and Lin, H. 2014, 'The Value Relevance of Accounting Numbers under International Financial Reporting Standards', Australian Accounting Review, 24 (3): 237-54.

Amihud, Y. 2002, 'Illiquidity and Stock Returns: Cross-Section and Time-Series Effects', Journal of Financial Markets, 5 (1): 31-56. 
Amihud, Y. and Mendelson, H. 1986, 'Asset Pricing and the Bid-Ask Spread', Journal of Financial Economics, 17 (2): 223 49.

Ashbaugh, H. 2001, 'Non-US Firms Accounting Standard Choices', Journal of Accounting and Public Policy, 20 (2): 129-53.

Aslan, H., Easley, D., Hvidkjaer, S. and O'Hara, M. 2011, 'The Characteristics of Informed Trading: Implications for Asset Pricing', Journal of Empirical Finance, 18 (5): 782-801.

Bae, K.H., Tan, H. and Welker, M. 2008, 'International GAAP Differences: The Impact on Foreign Analysts', The Accounting Review, 83 (3): 593-628.

Barth, M.E. and Israeli, D. 2013, 'Disentangling Mandatory IFRS Reporting and Changes in Enforcement', Journal of Accounting and Economics, 56 (2-3): 178-88.

Barth, M.E., Landsman, W.R. and Lang, M.H. 2008, 'International Accounting Standards and Accounting Quality', Journal of Accounting Research, 46 (3): 467-98.

Bharath, S.T., Pasquariello, P. and Guojun, W. 2009, 'Does Asymmetric Information Drive Capital Structure Decisions?', The Review of Financial Studies, 22 (8): 3211-43.

Brochet, F., Jagolinzer A.D. and Rield, E.J. 2013, 'Mandatory IFRS Adoption and Financial Statement Comparability', Contemporary Accounting Research, 30 (4): 1373-400.

Brown, S. and Hillegeist, S. 2007, 'How Disclosure Quality Affects the Level of Information Asymmetry', Review Accounting Studies, 12 (2-3): 443-77.

Brüggemann, U., Hitz, J.M. and Sellhorn, T. 2013, 'Intended and Unintended Consequences of Mandatory IFRS Adoption: A Review of Extant Evidence and Suggestions for Future Research', European Accounting Review, 22 (1): 1-37.

Byard, D., Li, Y. and Yu, Y. 2011, 'The Effect of Mandatory IFRS Adoption on Financial Analysts' Information Environment', Journal of Accounting Research, 49 (1): 69-96.

Choi, Y.S., Peasnell, K. and Toniato, J. 2013, 'Has the IASB Been Successful in Making Accounting Earnings More Useful for Prediction and Valuation? UK Evidence', Journal of Business Finance \& Accounting, 40 (7-8): 741-68.

Christensen, H., Hail, L. and Leuz, C. 2013, 'Mandatory IFRS Reporting and Changes in Enforcement', Journal of Accounting and Economics, 56 (2-3): 147-77.

Daske, H., Hail, L., Leuz, C. and Verdi, R. 2008, 'Mandatory IFRS Reporting around the World: Early Evidence on the Economic Consequences', Journal of Accounting Research, 46 (5): 1085-142.

Daske, H., Hail, L., Leuz, C. and Verdi, R. 2013, 'Adopting a Label: Heterogeneity in the Economic Consequences around IAS/IFRS Adoptions', Journal of Accounting Research, 51 (3): 495-547.

Diamond, M. 1985, 'Optimal Release of Information by Firms', The Journal of Finance, 40 (4): 1071-94.

Diamond, M. and Verrecchia, R. 1991, 'Disclosure, Liquidity and the Cost of Capital', The Journal of Finance, 46 (4): 1325-59.
European Communities. 2002, 'Regulation (EC) No 1606/2002 of the European Parliament and of the Council of 19 July 2002 on the Application of International Accounting Standards', Official Journal of the European Communities, L243, 1-4.

Easley, D., Hvidkjaer, S. and O'Hara, M. 2002, 'Is Information Risk a Determinant of Asset Returns?', The Journal of Finance, 57 (5): 2185-221.

Easley, D., Kiefer, N. and O'Hara, M. 1997, 'One Day in the Life of a Very Common Stock', The Review of Financial Studies, 10 (3): 805-35.

Easley, D., López de Prado, M.M. and O'Hara, M. 2012, 'Flow Toxicity and Liquidity in a High-Frequency World', The Review of Financial Studies, 25 (5): 1457-93.

Easley, D., Nicholas, M.K., O’Hara, M. and Paperman, J. 1996, 'Liquidity, Information, and Infrequently Traded Stocks', The Journal of Finance, 51 (4): 1405-36.

Easley, D. and O'Hara, M. 1987, 'Price, Trade Size, and Information in Securities Markets', The Journal of Financial Economics, 19 (1): 69-90.

Easley, D. and O'Hara, M. 1992, 'Time and the Process of Security Price Adjustment', The Journal of Finance, 47 (2): 577605.

Easley, D. and O'Hara, M. 2004, 'Information and the Cost of Capital', The Journal of Finance, 59 (4): 1553-83.

Gan, Q., Wei, W.C. and Johnstone, D. 2015, 'A Faster Estimation Method for the Probability of Informed Trading Using Hierarchical Agglomerative Clustering', Quantitative Finance, 15 (11): 1805-21.

Glosten, L.R. and Milgron, P.R. 1985, 'Bid, Ask and Transaction Prices in a Specialist Market with Heterogeneously Informed Traders', Journal of Financial Economics, 14 (1): 71-100.

Horton, J., Serafeim, G. and Serafeim, I. 2013, 'Does Mandatory IFRS Adoption Improve the Information Environment?' Contemporary Accounting Research, 30 (1): 388-423.

Huang, R. and Stoll, H. 1996, 'Dealer versus Auction Markets: A Paired Comparison of Execution Costs on NASDAQ and NYSE', Journal of Financial Economics, 41 (3): 313-57.

Kaufmann, D., Kraay, A. and Mastruzzi, M. 2009, 'Governance Matters VIII: Aggregate and Individual Governance Indicators 1996-2008', World Bank Policy Research, Washington, D.C., Working Paper No. 4978.

Kyle, A. 1985, 'Continuous Auctions and Insider Trading', Econometrica, 53 (6): 1315-35.

Lambert, R., Leuz, C. and Verrecchia, R.E. 2007, 'Accounting Information, Disclosure, and the Cost of Capital', Journal of Accounting Research, 45 (2): 385-420.

Lambert, R., Leuz, C. and Verrecchia, R.E. 2012, 'Information Asymmetry, Information Precision, and the Cost of Capital', Review of Finance, 16 (1): 1-29.

La Porta, R., Lopez de Salines, F., Shleifer, A. and Vishny, R.W. 1998, 'Law and Finance', Journal of Political Economy, 106 (6): 1113-55. 
Leuz, C. 2003, 'IAS versus US GAAP: Information AsymmetryBased Evidence from Germany's New Market', Journal of Accounting Research, 41 (3): 445-72.

Li, S. 2010, 'Does Mandatory Adoption of International Financial Reporting Standards in the European Union Reduce the Cost of Equity Capital?', The Accounting Review, 85 (2): 607-36.

Lin, H.W. and Ke, W.C., 2011, 'A Computing Bias in Estimating the Probability of Informed Trading', Journal of Financial Markets, 14 (4): 625-40.

Nobes, C. 2011, 'IFRS Practices and the Persistence of Accounting System Classification', Abacus, 47 (3): 267-83.
Petersen, M.A. 2009, 'Estimating Standard Errors in Finance Panel Data Sets: Comparing Approaches', Review of Financial Studies, 22 (1): 435-80.

Tan, H., Wang, S. and Welker, M. 2011, 'Analyst Following and Forecast Accuracy after Mandated IFRS Adoptions', Journal of Accounting Research, 49 (5): 130757.

Yan, Y. and Zhang, S. 2012, 'An Improved Estimation Method and Empirical Properties of the Probability of Informed Trading, Journal of Banking and Finance, 36 (2): 454-67. 
Journal: AUAR

Paper: auar12165

Dear Author

During the copy-editing of your paper, the following queries arose. Please respond to these by marking up your proofs with the necessary changes/additions. Please write your answers clearly on the query sheet if there is insufficient space on the page proofs. If returning the proof by fax do not write too close to the paper's edge. Please remember that illegible mark-ups may delay publication.

\begin{tabular}{|l|l|l|}
\hline Query No. & Description & Remarks \\
\hline Q1 & $\begin{array}{l}\text { Author: Please confirm that given names (red) and surnames/family names } \\
\text { green) have been identified correctly. }\end{array}$ & \\
\hline Q2 & Author: Please provide a short title running head. & \\
\hline Q3 & Author: Please check funding information and confirm its correctness. & \\
\hline
\end{tabular}


Required software to e-Annotate PDFs: Adobe Acrobat Professional or Adobe Reader (version 7.0 or above). (Note that this document uses screenshots from Adobe Reader $\mathrm{X}$ )

The latest version of Acrobat Reader can be downloaded for free at: http://get.adobe.com/uk/reader/

Once you have Acrobat Reader open on your computer, click on the Comment tab at the right of the toolbar:

닙

This will open up a panel down the right side of the document. The majority of tools you will use for annotating your proof will be in the Annotations section, pictured opposite. We've picked out some of these tools below:

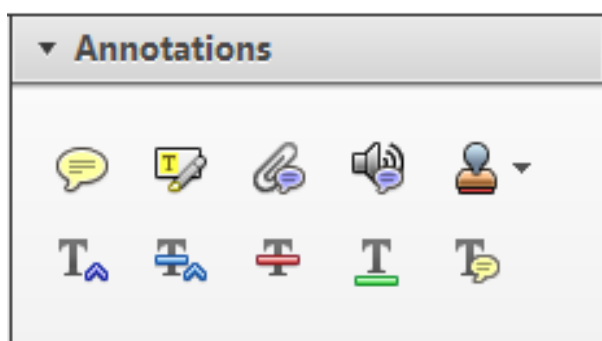

1. Replace (Ins) Tool - for replacing text.

Strikes a line through text and opens up a text box where replacement text can be entered.

How to use it

- Highlight a word or sentence.

- Click on the Replace (Ins) icon in the Annotations section.

- Type the replacement text into the blue box that appears.

Idard tramework for the analysis of $\mathrm{m}$ icy-Nevertheless, it also led to exog،

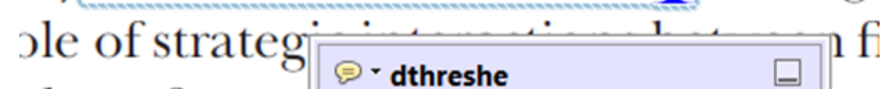
\begin{tabular}{l|l|l} 
aber of comp & 08/06/2011 15:58:17 & 0
\end{tabular} is that the $\mathrm{s} 1 \overline{\text {, which led }}$ of nain compo: be level, are exc nc

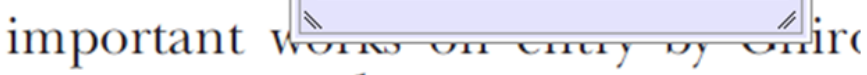
M heneferth) ${ }^{1}$ we anen the "hlarl $\mathrm{h}$

3. Add note to text Tool - for highlighting a section to be changed to bold or italic.

T Highlights text in yellow and opens up a text box where comments can be entered.

How to use it

- Highlight the relevant section of text.

- Click on the Add note to text icon in the Annotations section.

- Type instruction on what should be changed regarding the text into the yellow box that appears.

namic responses of mark ups ent with the VAR evidence

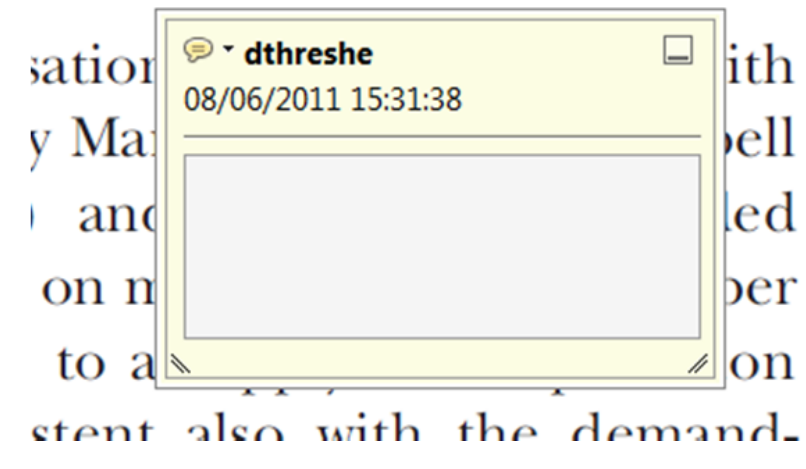

2. Strikethrough (Del) Tool - for deleting text.

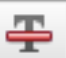

Strikes a red line through text that is to be deleted.

How to use it

- Highlight a word or sentence.

- Click on the Strikethrough (Del) icon in the Annotations section.

there is no room tor extra prohts al s ups are zero and the number of ret) values are not determined by Blanchard and Kiyotaki (1987), sfect competition in general equilil ts of aggregate demand and supply lassical framework assuming monol sen an evorenous number of firms

4. Add sticky note Tool - for making notes at specific points in the text.

Marks a point in the proof where a comment needs to be highlighted.

How to use it

- Click on the Add sticky note icon in the Annotations section.

- Click at the point in the proof where the comment should be inserted.

- Type the comment into the yellow box that appears.

iaisu airu suppiy sisuks. hivsl ui

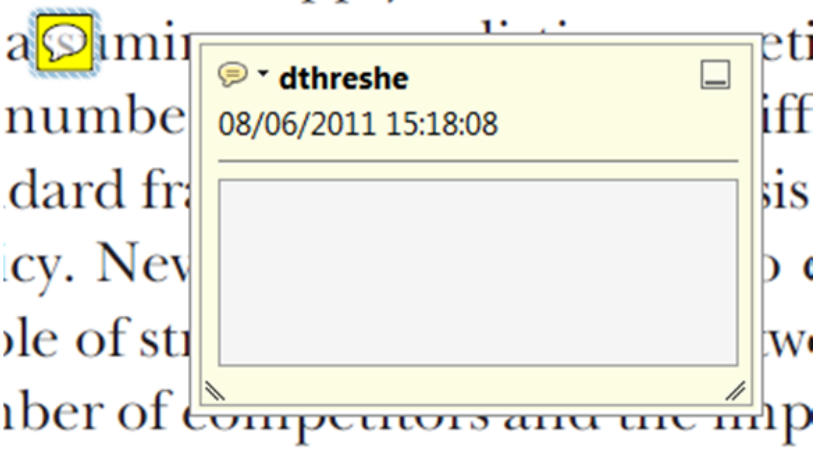

is that the structure of the sectc. 
5. Attach File Tool - for inserting large amounts of text or replacement figures.

Inserts an icon linking to the attached file in the appropriate pace in the text.

How to use it

- $\quad$ Click on the Attach File icon in the Annotations section.

- Click on the proof to where you'd like the attached file to be linked.

- Select the file to be attached from your computer or network.

- Select the colour and type of icon that will appear in the proof. Click OK.

E N D

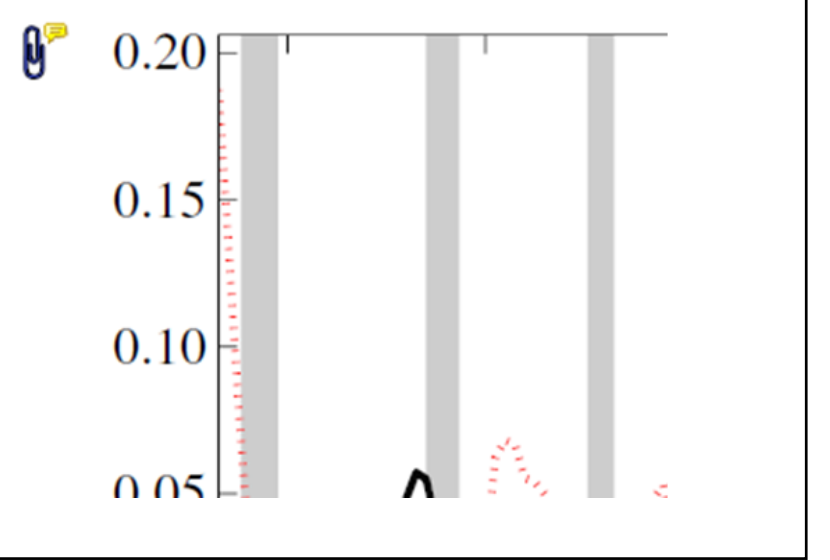

6. Add stamp Tool - for approving a proof if no corrections are required.

- Inserts a selected stamp onto an appropriate place in the proof.

\section{How to use it}

- $\quad$ Click on the Add stamp icon in the Annotations section.

- Select the stamp you want to use. (The Approved stamp is usually available directly in the menu that appears).

- Click on the proof where you'd like the stamp to appear. (Where a proof is to be approved as it is, this would normally be on the first page).

)t the Dusiness cycie, starting with the on perfect competition, constant ret

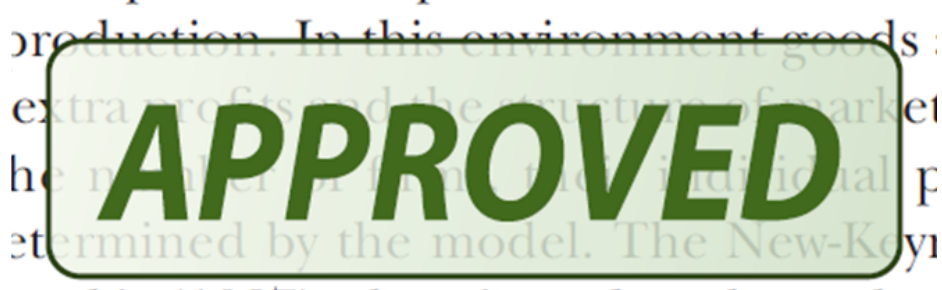
otaki (1987), has introduced produc general equilibrium models with nomin:

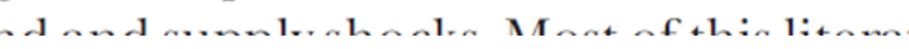

- Drawing Markups

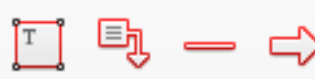

$0 \bigcirc \sqrt{6} \otimes$

\section{How to use it}

- Click on one of the shapes in the Drawing Markups section.

- Click on the proof at the relevant point and draw the selected shape with the cursor.

- To add a comment to the drawn shape, move the cursor over the shape until an arrowhead appears.

- Double click on the shape and type any text in the red box that appears.
7. Drawing Markups Tools - for drawing shapes, lines and freeform annotations on proofs and commenting on these marks.

Allows shapes, lines and freeform annotations to be drawn on proofs and for comment to be made on these marks.

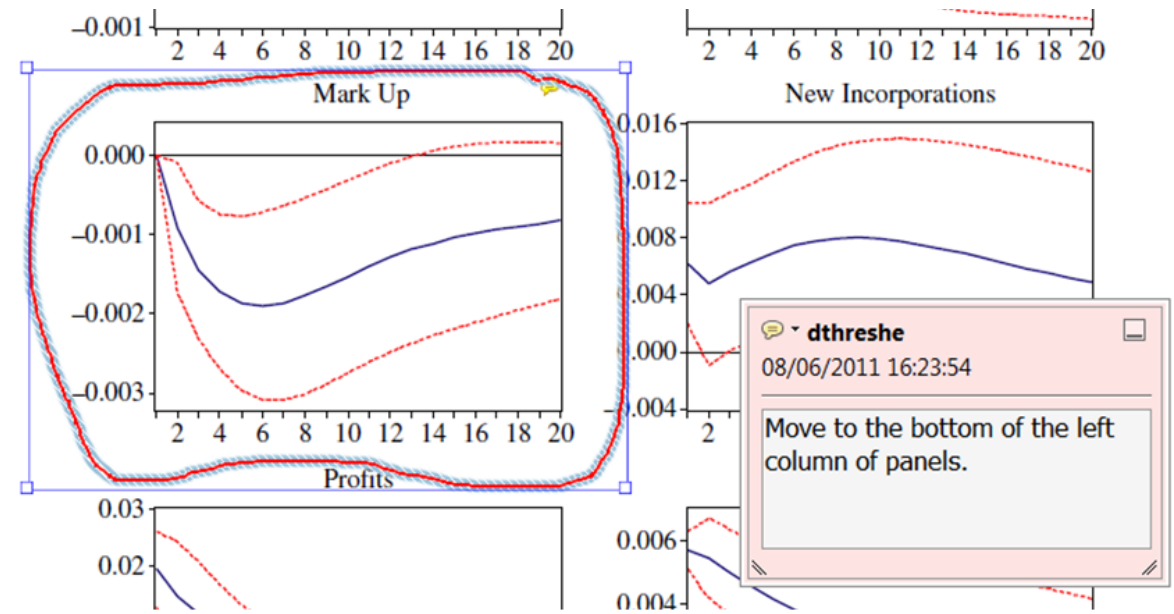

For further information on how to annotate proofs, click on the Help menu to reveal a list of further options:

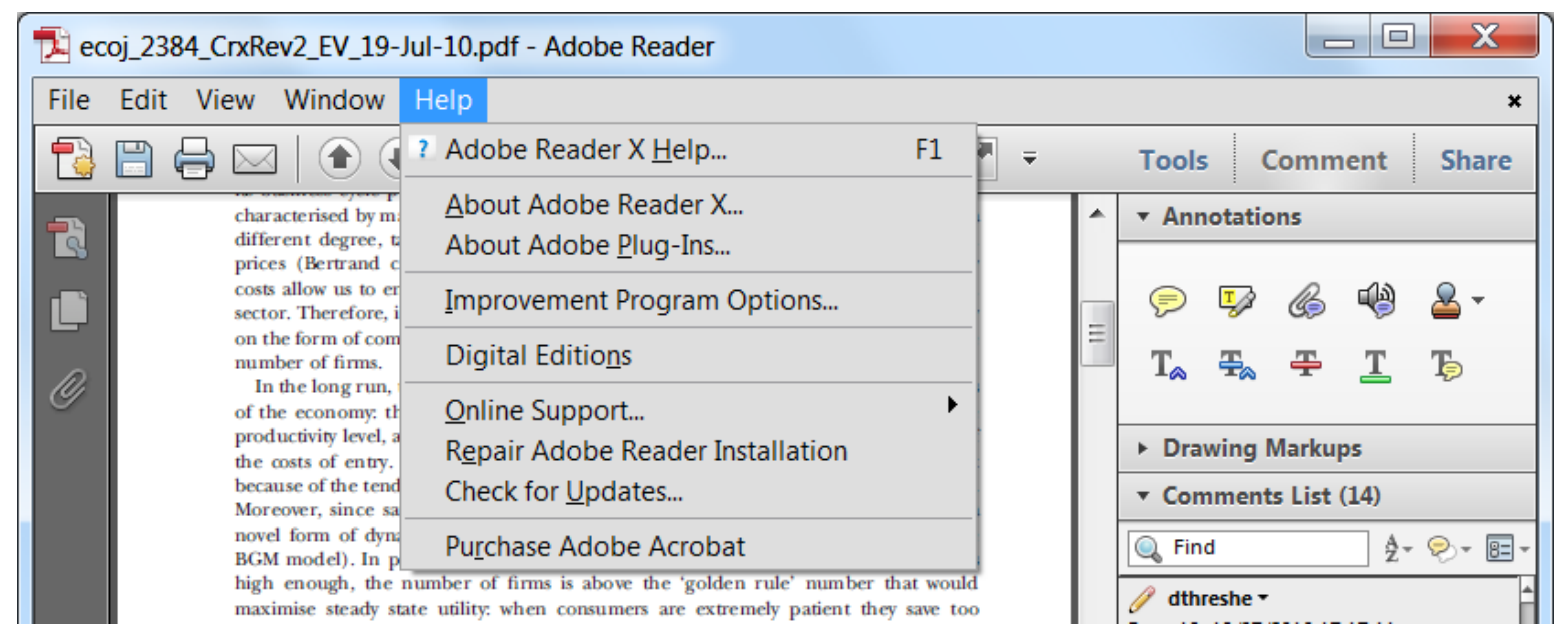

